\title{
14. EOLIAN AND SILICA DEPOSITION IN THE CENTRAL NORTH PACIFIC: RESULTS FROM SITES 885/886 1
}

\author{
Hilde Snoeckx, ${ }^{2}$ David K. Rea, ${ }^{2}$ Charles E. Jones, ${ }^{2}$ and B. Lynn Ingram ${ }^{3}$
}

\begin{abstract}
Sediments recovered at Ocean Drilling Program Sites 885/886 (central North Pacific Ocean at $44^{\circ} 41^{\prime} \mathrm{N}, 168^{\circ} 14^{\prime} \mathrm{W}$ and $44^{\circ} 41^{\prime} \mathrm{N}, 168^{\circ} 16^{\prime} \mathrm{W}$, respectively) record eolian deposition during the Cenozoic and late Mesozoic. We constructed a record of eolian MAR, which is a proxy for aridity/humidity of the climate in the continental source area. Eolian fluxes are low during the Late Cretaceous through Eocene, reflecting humid conditions in the source area. During the Oligocene, more arid climates prevailed at the source area, as indicated by increased eolian accumulation. The "Diatom Dump", an interval of enhanced silica deposition mainly apparent in the northwest Pacific, is reflected in the record at Sites $885 / 886$ by two- to fivefold higher opal fluxes compared with younger and older sediments. Increased eolian deposition starting at 3.5 Ma and culminating at 2-2.6 Ma are coincident with the onset of Northern Hemisphere glaciation. Sites $885 / 886$ lie $10^{\circ}$ north of sites examined previously for the history of eolian deposition in the central North Pacific and therefore allow enhanced understanding of the latitudinal variation of the wind system.
\end{abstract}

\section{INTRODUCTION}

One of the objectives of Ocean Drilling Program (ODP) Leg 145 was to investigate the history of Cenozoic and Late Cretaceous atmospheric circulation provided by eolian sediments in the North Pacific. For that purpose, Sites 885 and 886 were drilled $1 \mathrm{~km}$ apart at $44^{\circ} 41^{\prime} \mathrm{N}, 168^{\circ} 16^{\prime} \mathrm{W}$ and $168^{\circ} 14^{\prime} \mathrm{W}$, respectively, at about $5700 \mathrm{~m}$ water depth (Fig. 1). The sites are underneath the northern edge of the low-productivity zone of the central gyre. More importantly, they are located downwind from Asia, presumed to be the main source area for dust throughout the Cenozoic (Rea et al., 1985; Kyte et al., 1993; Nakai et al., 1993). Also, their location is sufficiently far removed from the continent to preclude influence of riverine input and ice-rafted debris.

The flux of windblown particles transported to the ocean is mainly dependent on the availability of deflatable material and therefore a proxy of humid-arid continental climate conditions (Prospero, 1981; Rea et al., 1985; Pye, 1989).

Earlier studies in the north Pacific Ocean covering the Cenozoic and late Mesozoic were performed on data from Deep Sea Drilling Project (DSDP) Site $576\left(32^{\circ} \mathrm{N}, 164^{\circ} \mathrm{E}\right)$ by Janecek (1985), piston Core LL44-GPC3 $\left(30^{\circ} \mathrm{N}, 158^{\circ} \mathrm{W}\right)$ by Janecek and Rea (1983), and DSDP Site $464\left(40^{\circ} \mathrm{N}, 174^{\circ} \mathrm{E}\right)$ by Rea and Harrsch (1981). This last site provided only a discontinuous record of eolian influx because of the low recovery and long hiatuses (Rea and Harrsch, 1985).

Whole Cenozoic records of eolian deposition were obtained from DSDP Site 576 and piston Core LL44-GPC3. During the Late Cretaceous and the Paleocene, eolian mass accumulation rates (MARs) at these sites were low, corresponding to warm and wet climates. During the middle to late Eocene the records of DSDP Site 576 and Core LL44-GPC3 show a decrease in eolian MARs that may be the result of a more humid climate in the eolian source region and/or the passage of those sites from one wind belt to another (Leinen and Heath, 1981; Janecek and Rea, 1983; Rea, 1994). Accumulation rates at those sites were found to be low in the Oligocene which contradicts the notion of drier climates in the Oligocene than in the Paleocene and Eocene suggested by other climatic data (Janecek, 1985).

${ }^{1}$ Rea, D.K., Basov, 1.A., Scholl, D.W., and Allan, J.F. (Eds.), 1995. Proc. ODP, Sci. Results, 145: College Station, TX (Ocean Drilling Program).

${ }^{2}$ Department of Geological Sciences, University of Michigan, 1006 C.C. Little Building, Ann Arbor, MI 48109-1063, U.S.A.

${ }^{3}$ Department of Geology and Geophysics, University of California, Berkeley, CA 94720, U.S.A.
The record obtained at Sites $885 / 886$, which are the northernmost sites studied thus far for their eolian signal, provides an opportunity to establish longitudinal transects and to make comparisons with data from farther to the south, such as at DSDP Site 576 and in Core LL44-GPC3.

\section{METHODS}

\section{Sample Strategy}

The eolian record for Sites $885 / 886$ was determined from samples from Holes $885 \mathrm{~A}, 886 \mathrm{~B}$, and $886 \mathrm{C}$. Samples were taken over the entire length of the sediment column of Holes $885 \mathrm{~A}$ and $886 \mathrm{~B}$ and the bottom of Hole $886 \mathrm{C}$ (Cores $7 \mathrm{H}$ and $8 \mathrm{H}$ ). The three holes, as well as Hole $886 \mathrm{~A}$, were placed on a common depth scale based on the magnetic susceptibility record, using the chemostratigraphy and dust records as independent controls (Dickens et al., this volume). The records for Holes $885 \mathrm{~A}$ and $886 \mathrm{~B}$ largely overlap, and drilling in Hole $886 \mathrm{C}$ extended the record to basement and provided a comfortable overlap of $8 \mathrm{~m}$ with Hole $886 \mathrm{~B}$. Samples from Holes $886 \mathrm{~B}$ and $886 \mathrm{C}$ were analyzed at a spacing of four samples per $1.5-\mathrm{m}$ section. Hole $885 \mathrm{~A}$ was analyzed with a sample frequency of two samples per section to provide a control; because of stratigraphic ambiguity in the top $10 \mathrm{~m}$ of Hole $886 \mathrm{~B}$ (Dickens et al., this volume), the sample frequency was increased to four samples per $1.5-\mathrm{m}$ section in the top $12.6 \mathrm{mbsf}$.

\section{Extraction of the Eolian Component}

The eolian component of the sediments was isolated using a modified version of the extraction procedure detailed by Rea and Janecek (1981). The procedure calls for the removal of calcium carbonate by acetic acid. Because Sites $885 / 886$ are beneath the calcite compensation depth, we did not expect to find $\mathrm{CaCO}_{3}$ in the sediment. Amorphous $\mathrm{Fe}$ and $\mathrm{Mn}$ oxides and hydroxides, as well as zeolites were removed with a buffered sodium citrate and sodium dithionite solution. The increased accumulation of hydrothermal material at the bottom of Hole 886C (Dickens and Owen, this volume) required repeated applications of this procedure. Parallel analyses of low oxy-hydroxide samples from the same site do not indicate additional clay loss after repeating this step. Opaline silica in the Rea and Janecek (1981) method is removed by sodium carbonate. However, this digestant is inadequate in removing all of the biogenous silica for sediments at these sites. Therefore, opal was dissolved by the harsher sodium hydroxide. Unlike Hovan's (in press) experience with equa- 


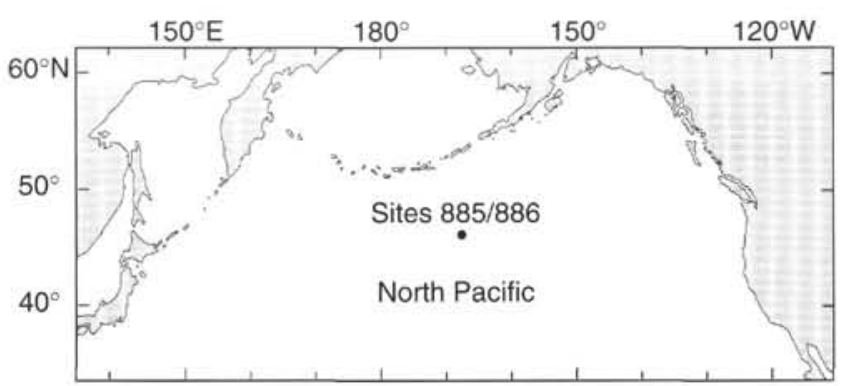

Figure 1. Map of the North Pacific Ocean showing Sites 885/886.

torial Pacific samples, we did not observe a quantifiable leaching of the crystalline silicate component. Different clay mineralogy and a relatively greater amount of dissolution-prone neoformational minerals in the low-dust equatorial sediments may explain the difference. The extraction procedure does not remove volcanic ash. We took care not to sample ash layers but samples younger than $2.6 \mathrm{Ma}$ may contain minute amounts of disseminated ash. Results of the extraction method are tabulated in Table 1 .

\section{Siliceous Component}

To the extent that sediments at Sites $885 / 886$ are a two-component system of biogenous silica and eolian dust (i.e., above $\sim 54$ meters composite depth [mcd]), the amount of opal can be estimated by the difference:

$$
\mathrm{wt} \% \text { opal }=100-\mathrm{wt} \% \text { dust. }
$$

Calculated amounts of opal are presented in Table 1.

\section{Mass Accumulation Rate Calculations}

The mass accumulation rate (MAR) is the product of the linear sedimentation rate (LSR) and the dry bulk density of the sample. The flux of the windblown component and of opal is the product of the percentage by weight of the respective component and the total sediment MAR. For example,

$$
\begin{gathered}
\text { eolian MAR }\left[\mathrm{g} /\left(\mathrm{cm}^{2} \cdot \mathrm{k} . \mathrm{y} .\right)\right]=\% \text { extracted } \times \operatorname{LSR}(\mathrm{cm} / \mathrm{k} . \mathrm{y} .) \\
\times \operatorname{DBD}\left(\mathrm{g} / \mathrm{cm}^{3}\right) .
\end{gathered}
$$

The MAR of the eolian and biogenous component was calculated based on assumptions related to depth, age, and dry bulk density of the sample as outlined below. All data are tabulated in Table 1. The accuracy of the MARs strongly depends on the accuracy of the stratigraphy. In view of the assumptions described here, care should be taken in interpreting the eolian flux. Changes in eolian MAR of less than $10 \%-20 \%$ above $52 \mathrm{mcd}$ (or $8.5 \mathrm{Ma}$ ) and of $50 \%-100 \%$ in the older sediments are geologically not significant.

\section{Dry Bulk Density}

Dry bulk density was calculated from onboard physical properties measurements (Rea, Basov, Janecek, Palmer-Julson, et al., 1993). One $10-\mathrm{cm}^{3}$ sample was taken per section. The index properties (wet-bulk density, grain density, water content, porosity, and dry-bulk density) were determined from measurements of wet and dry weights and dry volume (Rea, Basov, Janecek, Palmer-Julson, et al., 1993). We calculated dry bulk densities by interpolation between these known values.

\section{Composite Depth Scale}

The eolian record for Sites $885 / 886$ is a composite based on the record of three holes. Therefore, it was necessary to place all samples on a common depth scale, termed meters composite depth. To this end a composite depth scale was established (Dickens et al., this volume). Because of stratigraphic ambiguity in the top of Hole 886B, no composite depths are calculated for the interval between 0 and 10.25 mbsf. The composite depth scale for Sites 885/886 stretches the sediment column for each hole, by approximately $8 \%$ in the case of Hole $886 \mathrm{~B}$ to $10 \%$ for the top $10 \mathrm{~m}$ and $40 \%$ below $10 \mathrm{~m}$ in the case of Hole $885 \mathrm{~A}$. No stretching was done in Hole $886 \mathrm{C}$ for the depth interval studied. The use of a composite depth scale, therefore, may increase the LSR and would therefore lead to exaggerated MARs. The eolian record for Sites $885 / 886$ has been assembled from segments of the three holes: between 0 and $10.25 \mathrm{mcd}$ in samples from Hole $885 \mathrm{~A}$, from 10.25 to $60 \mathrm{mcd}$ in samples from Hole $886 \mathrm{~B}$, and from $60 \mathrm{mcd}$ to basement in samples from Hole $886 \mathrm{C}$. This composite record ensures that the error in the LSR caused by stretching or compression is minimal and negligible compared with the uncertainties in the time scale.

\section{Age Model}

The time scale adopted by the Leg 145 scientific party was constructed by Cande and Kent (1992). The age model (Fig. 2) for the upper $52 \mathrm{mcd}$ is based on the magnetic reversal stratigraphy (Rea, Basov, Janecek, Palmer-Julson, et al., 1993) and radiolarian stratigraphy (Morley and Nigrini, this volume). In general, radiolarian events support the magnetic reversal stratigraphy (Fig. 2). The age model based on these two stratigraphies is reliable to $8.5 \mathrm{Ma}$.

Below $53 \mathrm{mcd}$, the sediment column is devoid of identifiable microfossils except for occasional fish remains. As a consequence, the sedimentation rate drops to a level too low for reliable magnetostratigraphy. The age of the oldest sediment is constrained by the age of the basement, which is $80 \pm 1 \mathrm{Ma}$ (Keller and Duncan, this volume). The Cretaceous/Tertiary $(\mathrm{K} / \mathrm{T})$ stratum was placed in Core 145 $886 \mathrm{C}-8 \mathrm{H}$ between 130 and $145 \mathrm{~cm}$, which corresponds to $63.25-63.4$ mcd (Kyte and Zhou, this volume). A time resolution of three strata, which are 56.5 and 15 m.y. apart, respectively, inhibits the study of any climatic or geologic signals for this period. To improve the time resolution, the Sr-isotope stratigraphy determined from ichthyoliths was used as an alternative dating method (Ingram, this volume). All stratigraphic data considered for the age model are presented in Table 2.

\section{Sr Isotopes and Fish Teeth: A Tartar Removal Experiment}

The Sr-isotope seawater curve recorded by ichthyoliths promises to provide a useful relative dating method for red-clay sites, where dating traditionally has been difficult. Previous work on fish teeth showed that, although they can retain ${ }^{87} \mathrm{Sr} /{ }^{86} \mathrm{Sr}$ signatures that are close to the primary marine signal (Staudigel et al., 1985), several samples did in fact yield ${ }^{87} \mathrm{Sr} /{ }^{86} \mathrm{Sr}$ ratios that were significantly different from what would be expected from their stratigraphic ages. We picked fish teeth from eight samples from Hole $886 \mathrm{C}$ for $\mathrm{Sr}$ isotopic analysis. The main goal of this pilot study was to determine whether the main source of error in ichthyolith analyses resides in the Fe-Mn oxide coatings commonly found on fish teeth, in the incomplete cleaning of samples, or in the preservation of the fish teeth themselves.

Fish teeth handpicked from sieved sediment samples were washed with distilled water. To remove any transition-metal oxide coatings, all samples were subjected to the reductive dissolution technique described by Mehra and Jackson (1960) and Rea and Janecek (1981). Two $\mathrm{mL}$ of $0.3 \mathrm{M}$ sodium citrate and $0.25 \mathrm{~mL}$ of $1.0 \mathrm{M}$ sodium bicarbonate were added to each beaker and heated to near-boiling. Then, approximately $0.05 \mathrm{~g}$ of sodium dithionite was added and the capped Teflon perfluoralkoxy (PFA) beakers were placed in an ultrasonic bath for $30 \mathrm{~min}$. Because of the very small sample size, just one application of this treatment appeared to remove all visible Fe-oxide coatings. Before this treatment, samples from greater depths (Table 3 ) appeared under a binocular microscope to be heavily coated with $\mathrm{Fe}$ oxides and to have their hollow cores also filled with oxides. After the 
reductive dissolution, all fish teeth except for two exceptionally large specimens ( $\sim \mathrm{mm}$ in length) became translucent such that it was difficult to see them against their semitranslucent Teflon background. No sign of oxide staining or residual clay minerals was present on either the outside or inside of any tooth. The two large teeth, one of which had been bored and appeared to be (bio?)corroded (Table 3), were too large to be translucent; nevertheless they showed no sign of oxide staining on the outside surfaces. Because of the translucence of the teeth, it was necessary to use a pipette under the binocular microscope to avoid losing the fish teeth while decanting the reductive solution. The samples were then rinsed twice using $7 \mathrm{~mL}$ of ultrapure water and placed in the ultrasonic bath for 30 minutes. This rinsing was intended to remove as much as possible of the $\mathrm{Sr}$ associated with both the Fe oxide coatings and with the reagents used for the reductive dissolution. The fish teeth were then transferred to fresh acid-cleaned Teflon beakers, dissolved in $0.2 \mathrm{~mL} 3 \mathrm{M}$ ultrapure nitric acid, and loaded onto SrSpec columns with a resin bed volume of $0.07 \mathrm{~mL}$. Major elements were eluted with $1 \mathrm{~mL} 3 \mathrm{M}$ nitric acid, and the purified $\mathrm{Sr}$ was collected in $1 \mathrm{~mL}$ of water. The $\mathrm{Sr}$ was loaded onto $\mathrm{Re}$ single filaments with a $\mathrm{TaCl}_{5}$ solution and $5 \%$ phosphoric acid and analyzed on a VG Sector multicollector thermal ionization mass spectrometer in multidynamic analysis mode. Samples were normalized to ${ }^{86} \mathrm{Sr} /{ }^{88} \mathrm{Sr}=0.1194$; total procedural blanks were $<40 \mathrm{pg}$. The sample details and $\mathrm{Sr}$ isotopic results are presented in Table 3.

It seems possible that the somewhat scattered results of Staudigel et al. (1985) are caused by the variable inclusion of contaminant $\mathrm{Sr}$ associated with the Fe-Mn oxide coatings. Our results support the likelihood that fish teeth retain a primary marine ${ }^{87} \mathrm{Sr} /{ }^{86} \mathrm{Sr}$ signature. However, despite this important result, the data presented in Table 3 should still be viewed with some caution. For example, the Ir anomaly was located about $30 \mathrm{~cm}$ above interval $145-886 \mathrm{C}-8 \mathrm{H}-2,10-15 \mathrm{~cm}$ (Kyte, this volume), thus dating this sample as older than the $\mathrm{K} / \mathrm{T}$ boundary. However, the ${ }^{87} \mathrm{Sr} /{ }^{86} \mathrm{Sr}$ ratio of the fish teeth from this level would indicate an age of approximately $33 \mathrm{Ma}$, based on a comparison with the seawater $\mathrm{Sr}$-isotope record. It would require a lowering of the measured ratio by roughly 0.000080 to be consistent with a latest Cretaceous age. In addition, a sample taken from interval $145-886 \mathrm{C}$ $7 \mathrm{H}-6,10-15 \mathrm{~cm}$, and analyzed by Ingram (this volume) has yielded a ${ }^{87} \mathrm{Sr}{ }^{86} \mathrm{Sr}$ ratio 0.000080 higher than the ratio measured in this work. Fish teeth from this level do not have visible coatings; our cleaning procedure, therefore, is less likely to have removed any contaminating $\mathrm{Sr}$ associated with any oxide phases. The fact that intervals $145-886 \mathrm{C}$ $8 \mathrm{H}-2,10-15 \mathrm{~cm}$, and $-7 \mathrm{H}-6,10-15 \mathrm{~cm}$ yielded ratios that appear to be too high may indicate that there may be some contamination associated with a residual amount of the reductive dissolution reagents. Because the fish teeth were transferred to fresh beakers, this potential contamination, which was not removed by the double water rinses, may be either associated with material on the fish tooth surfaces or with material left in the tiny conical cavities of the fish teeth. Any future work on fish teeth should include more rigorous rinsing, perhaps with a pure ammonium chloride solution or acetic acid (cf. Bertram et al., 1992).

\section{Backtrack and Paleolatitude (Paleoposition)}

Because wind patterns may change in time and space, it is fundamental to the interpretation of the eolian signal to know the paleoposition of Sites $885 / 886$. The backtrack path (Fig. 3) was drawn after the model proposed by van Andel et al. (1975) and modified by Prince (1978). The same model was used by Leinen and Heath (1981) for piston Core LL44-GPC-3.

\section{RESULTS}

\section{Eolian Abundance}

The eolian dust record shows very good agreement among the different holes (Fig. 4) and presents an independent test for the composite depth scale (Dickens et al., this volume).
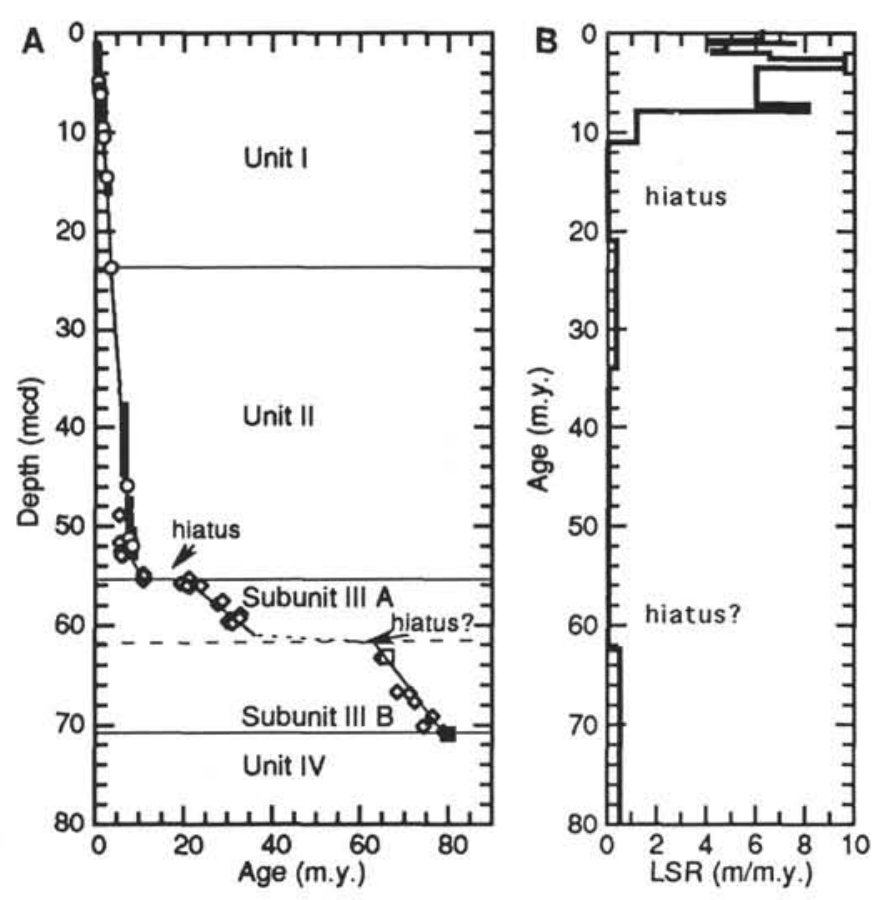

Figure 2. A. Age-depth model for Sites $885 / 886$ based on magnetic reversal stratigraphy (Rea, Basov, et al., 1993), radiolarian stratigraphy (Morley and Nigrini, this volume), Sr-isotope stratigraphy (Ingram, this volume; this paper), Ir anomaly (Kyte and Zhou, this volume), and Ar/Ar dating (Keller and Duncan, this volume). Open circles represent paleomagnetic reversals; diamonds represent ichthyoliths (fish teeth), the open square represents the Ir anomaly that indicates the Cretaceous/Tertiary boundary; and the closed square represents basement. Solid thick lines represent the depth range of radiolarian events. Also shown are lithologic units from Rea, Basov, Janecek, PalmerJulson, et al. (1993), as modified by Dickens et al. (this volume). B. Linear sedimentation rates calculated from the age-depth model.

Three major lithologic units are recognized in Sites 885/886 (Fig. 5) (Rea, Basov, Janecek, Palmer-Julson, et al., 1993). The boundaries of the units described here have been adjusted to the composite depth scale according to Dickens et al. (this volume). Unit I, between 0 and 23.75 mcd, consists mainly of clay with diatoms; Unit II, between 23.75 and $53 \mathrm{mcd}$, of diatom ooze and clayey diatom ooze; and Unit III of clay and hematitic clay (Rea, Basov, Janecek, Palmer-Julson, et al., 1993). A reinterpretation of Unit III suggests subdivision at 62 med into Subunit IIIA, which is predominantly clay, and Subunit IIIB, which consists mainly of distal hydrothermal Fe-Mn precipitates (Dickens et al., this volume). The abundance of extracted eolian material in Unit I is $40 \%-55 \%$ (Fig. 5) in the top $18 \mathrm{mcd}$ and decreases gradually to $20 \%$ toward the bottom of this unit. A sharp plunge in the percentage of eolian material occurs at approximately 16 mcd (Fig. 5). This anomalous interval is also present in the geochemical record (Dickens et al., this volume). Unit II is marked by two lithologies: diatom ooze above 48 mcd and clayey diatom ooze below. Within the diatom ooze interval, there are two levels in eolian abundances: above 35 mcd eolian abundance is low (10\% or less) whereas below $35 \mathrm{mcd}$, abundance varies from $10 \%$ to $20 \%$ (Fig. 5). In the clayey diatom ooze (between 48 and $55 \mathrm{mcd}$ ) the eolian component varies from $20 \%$ to $45 \%$ (Fig. 5). Subunit IIIA contains $25 \%$ to $40 \%$ dust, whereas the amount of extracted material decreases to nearly nil toward the basement in Subunit IIIB (Fig. 5).

\section{Opal Abundance}

As expected, the record of opal is the mirror image of the eolian record (Figs. 5 and 6). The amount of biogenic silica is roughly equal to the windblown sediment in the top $18 \mathrm{~m}$ of the sediment column, 
Table 1. Data from Sites $\mathbf{8 8 5} / \mathbf{8 8 6}$.

\begin{tabular}{|c|c|c|c|c|c|c|c|c|c|}
\hline $\begin{array}{l}\text { Core, section } \\
\text { interval }(\mathrm{cm})\end{array}$ & $\begin{array}{l}\text { Depth } \\
\text { (mbsf) }\end{array}$ & $\begin{array}{l}\text { Depth } \\
\text { (mcd) }\end{array}$ & $\begin{array}{c}\text { Age } \\
(\mathrm{m} . \mathrm{y} .)\end{array}$ & $\begin{array}{c}\text { LSR } \\
(\mathrm{m} / \mathrm{m} . \mathrm{y} \cdot)\end{array}$ & $\begin{array}{c}\text { DBD } \\
\left(\mathrm{g} / \mathrm{cm}^{3}\right)\end{array}$ & $\begin{array}{l}\text { Eolian } \\
(w t \%)\end{array}$ & $\begin{array}{c}\text { Eolian MAR } \\
\left(\mathrm{mg} /\left[\mathrm{cm}^{2} \cdot \mathrm{k} . \mathrm{y} .\right]\right)\end{array}$ & $\begin{array}{l}\text { Opal } \\
(w t \%)\end{array}$ & $\begin{array}{c}\text { Opal MAR } \\
\left(\mathrm{mg} /\left[\mathrm{cm}^{2} \cdot \mathrm{k} . \mathrm{y} \cdot\right]\right)\end{array}$ \\
\hline $145-885 \mathrm{~A}-$ & & & & & & & & & \\
\hline $1 \mathrm{H}-1,30-35$ & 0.30 & 0.35 & 0.06 & 6.3 & 0.47 & 45.6 & 134 & 54.4 & 160 \\
\hline $1 \mathrm{H}-1,55-60$ & 0.55 & 0.71 & 0.11 & 6.3 & 0.47 & 47.9 & 141 & 52.1 & 153 \\
\hline $1 \mathrm{H}-1,105-110$ & 1.05 & 1.40 & 0.22 & 6.3 & 0.46 & 51.0 & 148 & 49.0 & 142 \\
\hline $1 \mathrm{H}-1,130-135$ & 1.30 & 1.71 & 0.27 & 6.3 & 0.46 & 52.4 & 150 & 47.6 & 137 \\
\hline $1 \mathrm{H}-2,30-35$ & 1.80 & 2.40 & 0.38 & 6.3 & 0.45 & 48.1 & 135 & 51.9 & 145 \\
\hline $1 \mathrm{H}-2,55-60$ & 2.05 & 2.74 & 0.44 & 6.3 & 0.44 & 52.3 & 145 & 47.7 & 132 \\
\hline $1 \mathrm{H}-2,105-110$ & 2.55 & 3.47 & 0.55 & 6.3 & 0.45 & 48.9 & 139 & 51.1 & 145 \\
\hline $1 \mathrm{H}-3,30-35$ & 3.30 & 4.47 & 0.71 & 6.3 & 0.48 & 36.9 & 111 & 63.1 & 189 \\
\hline $1 \mathrm{H}-3,55-60$ & 3.55 & 4.60 & 0.74 & 6.3 & 0.49 & 38.9 & 119 & 61.2 & 187 \\
\hline $1 \mathrm{H}-3,105-110$ & 4.05 & 5.00 & 0.81 & 4.1 & 0.50 & 50.5 & 103 & 49.5 & 101 \\
\hline $1 \mathrm{H}-3,130-135$ & 4.30 & 5.25 & 0.87 & 4.1 & 0.50 & 52.5 & 107 & 47.5 & 97 \\
\hline $2 \mathrm{H}-1,30-35$ & 4.90 & 5.65 & 0.97 & 4.1 & 0.51 & 54.0 & 111 & 46.1 & 95 \\
\hline $2 \mathrm{H}-1,55-60$ & 5.15 & 5.91 & 1.01 & 7.5 & 0.51 & 50.8 & 195 & 49.2 & 189 \\
\hline $2 \mathrm{H}-1.105-110$ & 5.65 & 6.46 & 1.10 & 4.8 & 0.50 & 49.4 & 118 & 50.6 & 121 \\
\hline $2 \mathrm{H}-1,130-135$ & 5.90 & 6.73 & 1.16 & 4.8 & 0.49 & 45.6 & 107 & 54.4 & 128 \\
\hline $2 \mathrm{H}-2,30-35$ & 6.40 & 7.27 & 1.28 & 4.8 & 0.47 & 47.0 & 107 & 53.0 & 121 \\
\hline $2 \mathrm{H}-2,53-58$ & 6.63 & 7.52 & 1.33 & 4.8 & 0.47 & 40.4 & 91 & 59.6 & 134 \\
\hline $2 \mathrm{H}-2,105-110$ & 7.15 & 8.01 & 1.43 & 4.8 & 0.47 & 45.5 & 104 & 54.5 & 124 \\
\hline $2 \mathrm{H}-2,130-135$ & 7.40 & 8.23 & 1.48 & 4.8 & 0.49 & 45.0 & 105 & 55.0 & 128 \\
\hline $2 \mathrm{H}-3,30-35$ & 7.90 & 8.67 & 1.57 & 4.8 & 0.51 & 40.6 & 99 & 59.4 & 145 \\
\hline $2 \mathrm{H}-3,55-60$ & 8.15 & 8.90 & 1.62 & 4.8 & 0.52 & 49.8 & 125 & 50.2 & 125 \\
\hline $2 \mathrm{H}-3,105-110$ & 8.65 & 9.42 & 1.73 & 4.8 & 0.51 & 50.1 & 121 & 49.9 & 121 \\
\hline $2 \mathrm{H}-3,130-135$ & 8.90 & 9.77 & 1.81 & 4.3 & 0.49 & 40.4 & 84 & 59.6 & 124 \\
\hline $2 \mathrm{H}-4,30-35$ & 9.40 & 10.43 & 1.96 & 4.3 & 0.45 & 48.0 & 92 & 52.0 & 99 \\
\hline $2 \mathrm{H}-4,105-110$ & 10.15 & 11.76 & 2.17 & 6.6 & 0.42 & 40.1 & 110 & 59.9 & 165 \\
\hline $2 \mathrm{H}-4,130-135$ & 10.40 & 12.32 & 2.26 & 6.6 & 0.42 & 47.0 & 131 & 53.0 & 148 \\
\hline $2 \mathrm{H}-5,30-35$ & 10.90 & 1.35 & 2.41 & 6.6 & 0.44 & 41.3 & 119 & 58.7 & 169 \\
\hline $2 \mathrm{H}-5,55-60$ & 11.15 & 13.85 & 2.49 & 6.6 & 0.44 & 31.4 & 92 & 68.6 & 201 \\
\hline $2 \mathrm{H}-5,105-110$ & 11.65 & 14.73 & 2.62 & 6.6 & 0.43 & 43.2 & 123 & 56.8 & 162 \\
\hline $2 \mathrm{H}-5,130-135$ & 11.90 & 15.07 & 2.67 & 6.6 & 0.42 & 38.5 & 106 & 61.5 & 170 \\
\hline $2 \mathrm{H}-6,30-35$ & 12.40 & 15.76 & 2.72 & 9.6 & 0.39 & 14.7 & 56 & 85.3 & 323 \\
\hline $2 \mathrm{H}-6,55-60$ & 12.65 & 16.10 & 2.76 & 9.6 & 0.38 & 22.9 & 84 & 77.1 & 282 \\
\hline $2 \mathrm{H}-6,105-110$ & 13.15 & 16.79 & 2.83 & 9.6 & 0.37 & 26.2 & 93 & 73.8 & 261 \\
\hline $2 \mathrm{H}-6,130-135$ & 13.40 & 17.11 & 2.86 & 9.6 & 0.37 & 24.2 & 85 & 75.8 & 268 \\
\hline $3 \mathrm{H}-1,30-35$ & 14.40 & 20.00 & 3.16 & 9.6 & 0.36 & 22.4 & 78 & 77.6 & 270 \\
\hline $3 \mathrm{H}-1,105-110$ & 15.15 & 21.12 & 3.28 & 9.6 & 0.37 & 19.5 & 70 & 80.5 & 290 \\
\hline $3 \mathrm{H}-2,30-35$ & 15.90 & 22.60 & 3.43 & 9.6 & 0.41 & 18.9 & 75 & 81.1 & 319 \\
\hline $3 \mathrm{H}-2,105-110$ & 16.65 & 23.35 & 3.51 & 9.6 & 0.41 & 13.2 & 52 & 86.8 & 342 \\
\hline $3 \mathrm{H}-3,30-35$ & 17.40 & 24.10 & 3.61 & 6.0 & 0.36 & 10.0 & 22 & 90.1 & 195 \\
\hline $3 \mathrm{H}-3,105-110$ & 18.15 & 24.85 & 3.74 & 6.0 & 0.33 & 10.0 & 20 & 90.0 & 178 \\
\hline $3 \mathrm{H}-4,30-35$ & 18.90 & 25.60 & 3.86 & 6.0 & 0.32 & 8.6 & 17 & 91.4 & 178 \\
\hline $3 \mathrm{H}-4,105-110$ & 19.65 & 26.35 & 3.98 & 6.0 & 0.31 & 9.4 & 18 & 90.6 & 171 \\
\hline $3 \mathrm{H}-5,30-35$ & 20.40 & 27.10 & 4.11 & 6.0 & 0.30 & 8.0 & 14 & 92.0 & 166 \\
\hline $3 \mathrm{H}-5,105-110$ & 21.15 & 17.85 & 4.23 & 6.0 & 0.29 & 5.2 & 9 & 94.8 & 167 \\
\hline $3 \mathrm{H}-6,30-35$ & 21.90 & 28.60 & 4.36 & 6.0 & 0.30 & 5.3 & 9 & 94.7 & 169 \\
\hline $3 \mathrm{H}-6,105-110$ & 22.65 & 29.35 & 4.48 & 6.0 & 0.32 & 3.5 & 7 & 96.5 & 186 \\
\hline $3 \mathrm{H}-1,30-35$ & 23.40 & 30.10 & 4.61 & 6.0 & 0.37 & 3.3 & 7 & 96.7 & 216 \\
\hline $4 \mathrm{H}-1,30-35$ & 23.90 & 29.45 & 4.50 & 6.0 & 0.39 & 4.2 & 10 & 95.8 & 224 \\
\hline $4 \mathrm{H}-\mathrm{I}, 105-110$ & 24.65 & 30.20 & 4.62 & 6.0 & 0.30 & 4.2 & 7 & 95.8 & 170 \\
\hline $4 \mathrm{H}-2,30-35$ & 25.40 & 30.95 & 4.75 & 6.0 & 0.31 & 4.8 & 9 & 95.2 & 178 \\
\hline $4 \mathrm{H}-2,105-110$ & 26.15 & 31.70 & 4.87 & 6.0 & 0.34 & 5.7 & 12 & 94.3 & 191 \\
\hline $4 \mathrm{H}-3,30-35$ & 26.90 & 32.40 & 4.99 & 6.0 & 0.38 & 4.6 & 11 & 95.4 & 216 \\
\hline $4 \mathrm{H}-3,105-110$ & 27.65 & 33.06 & 5.10 & 6.0 & 0.40 & 18.0 & 43 & 82.0 & 196 \\
\hline $4 \mathrm{H}-4,30-35$ & 28.40 & 33.71 & 5.21 & 6.0 & 0.39 & 12.6 & 29 & 87.4 & 203 \\
\hline $4 \mathrm{H}-4,105-110$ & 29.15 & 34.36 & 5.32 & 6.0 & 0.39 & 8.7 & 20 & 91.3 & 216 \\
\hline $4 \mathrm{H}-5,28-33$ & 29.88 & 35.00 & 5.42 & 6.0 & 0.42 & 18.5 & 47 & 81.5 & 207 \\
\hline $4 \mathrm{H}-5,105-110$ & 30.65 & 35.82 & 5.56 & 6.0 & 0.43 & 16.2 & 42 & 83.8 & 216 \\
\hline $4 \mathrm{H}-6,30-35$ & 31.60 & 36.87 & 5.73 & 6.0 & 0.39 & 12.0 & 28 & 88.0 & 206 \\
\hline $4 \mathrm{H}-6,105-110$ & 32.15 & 37.48 & 5.83 & 6.0 & 0.42 & 9.7 & 25 & 90.3 & 229 \\
\hline $4 \mathrm{H}-1,30-35$ & 32.90 & 38.17 & 5.95 & 6.0 & 0.52 & 17.2 & 54 & 82.8 & 260 \\
\hline $5 \mathrm{H}-1,30-35$ & 33.40 & 39.20 & 6.12 & 6.0 & 0.56 & 20.5 & 70 & 79.5 & 270 \\
\hline $5 \mathrm{H}-1,105-110$ & 34.15 & 39.95 & 6.24 & 6.0 & 0.43 & 23.2 & 60 & 76.8 & 199 \\
\hline $5 \mathrm{H}-2,30-35$ & 34.90 & 40.74 & 6.37 & 6.0 & 0.39 & 12.1 & 28 & 87.9 & 205 \\
\hline $5 \mathrm{H}-2,105-110$ & 35.65 & 41.69 & 6.53 & 6.0 & 0.37 & 17.1 & 38 & 82.9 & 183 \\
\hline $5 \mathrm{H}-3,30-35$ & 36.40 & 42.72 & 6.70 & 6.0 & 0.38 & 14.1 & 32 & 85.9 & 197 \\
\hline $5 \mathrm{H}-3,105-110$ & 37.15 & 43.66 & 6.86 & 6.0 & 0.38 & 10.1 & 23 & 89.9 & 206 \\
\hline $5 \mathrm{H}-4,30-35$ & 37.90 & 44.55 & 7.01 & 6.0 & 0.35 & 9.7 & 21 & 90.3 & 193 \\
\hline $5 \mathrm{H}-4,105-110$ & 38.65 & 45.44 & 7.16 & 6.0 & 0.37 & 11.2 & 25 & 88.8 & 198 \\
\hline $5 \mathrm{H}-5,30-35$ & 39.40 & 46.34 & 7.29 & 8.1 & 0.45 & 14.4 & 52 & 85.6 & 311 \\
\hline $5 \mathrm{H}-5,105-110$ & 40.15 & 47.23 & 7.40 & 8.1 & 0.49 & 25.1 & 99 & 74.9 & 296 \\
\hline $5 \mathrm{H}-6,30-35$ & 40.90 & 48.19 & 7.52 & 8.1 & 0.48 & 35.0 & 136 & 65.0 & 252 \\
\hline $5 \mathrm{H}-6,105-110$ & 41.65 & 49.21 & 7.64 & 8.1 & 0.46 & 30.9 & 116 & 69.1 & 258 \\
\hline $5 \mathrm{H}-1,30-35$ & 42.40 & 50.10 & 7.75 & 8.1 & 0.43 & 28.1 & 99 & 71.9 & 254 \\
\hline $6 \mathrm{H}-1,30-35$ & 42.90 & 50.60 & 7.81 & 8.1 & 0.41 & 27.1 & 90 & 72.9 & 242 \\
\hline $6 \mathrm{H}-1,105-110$ & 43.65 & 51.44 & 8.05 & 1.2 & 0.39 & 34.6 & 16 & 65.4 & 30 \\
\hline $6 \mathrm{H}-2,30-35$ & 44.40 & 52.38 & 8.84 & 1.2 & 0.42 & 45.7 & 23 & 54.3 & 28 \\
\hline $6 \mathrm{H}-2,105-110$ & 45.15 & 53.15 & 9.47 & 1.2 & 0.44 & 50.8 & 27 & 49.2 & 27 \\
\hline $6 \mathrm{H}-3,30-35$ & 45.90 & 53.82 & 10.02 & 1.2 & 0.45 & 44.5 & 24 & & \\
\hline $6 \mathrm{H}-3,105-110$ & 46.65 & 54.50 & 10.58 & 1.2 & 0.49 & 46.7 & 28 & & \\
\hline $6 \mathrm{H}-4,30-35$ & 47.40 & 55.17 & 11.13 & 1.2 & 0.57 & 42.4 & 29 & & \\
\hline $6 \mathrm{H}-4,105-110$ & 48.15 & 55.66 & 21.36 & 0.4 & 0.58 & 46.0 & 10 & & \\
\hline $6 \mathrm{H}-5,30-35$ & 48.90 & 59.04 & 30.40 & 0.4 & 0.49 & 37.6 & 7 & & \\
\hline $6 \mathrm{H}-5,105-110$ & 49.65 & 62.40 & 64.15 & 0.5 & 0.44 & 30.6 & 7 & & \\
\hline $6 \mathrm{H}-6,30-35$ & 50.40 & 63.15 & 65.54 & 0.5 & 0.45 & 22.5 & 5 & & \\
\hline $6 \mathrm{H}-6,105-110$ & 51.15 & 69.79 & 77.84 & 0.5 & 0.45 & 6.1 & 1 & & \\
\hline $6 \mathrm{H}-1,30-35$ & 51.78 & 70.38 & 78.94 & 0.5 & 0.42 & 4.9 & 1 & & \\
\hline
\end{tabular}


Table 1 (continued).

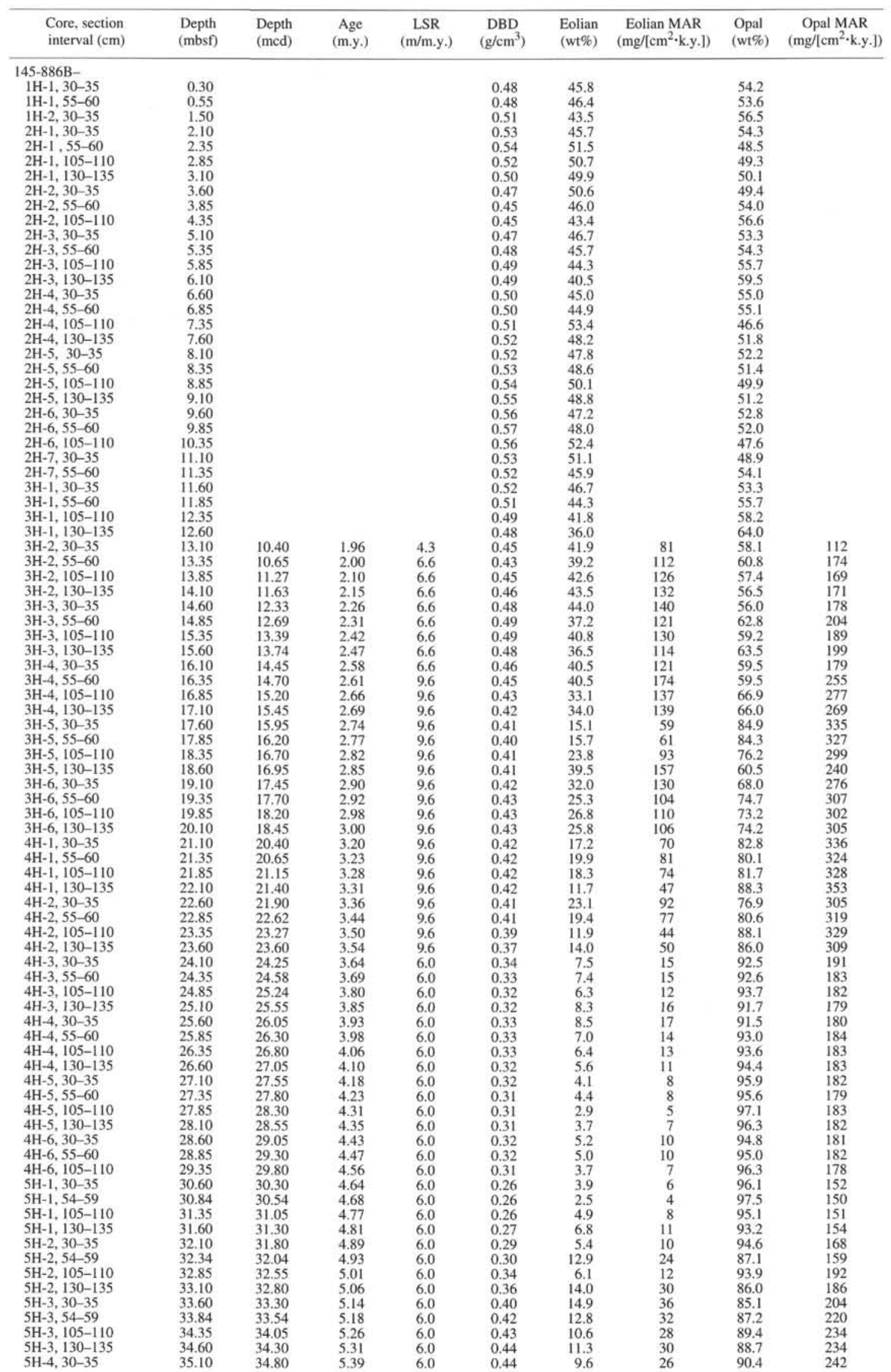


Table 1 (continued).

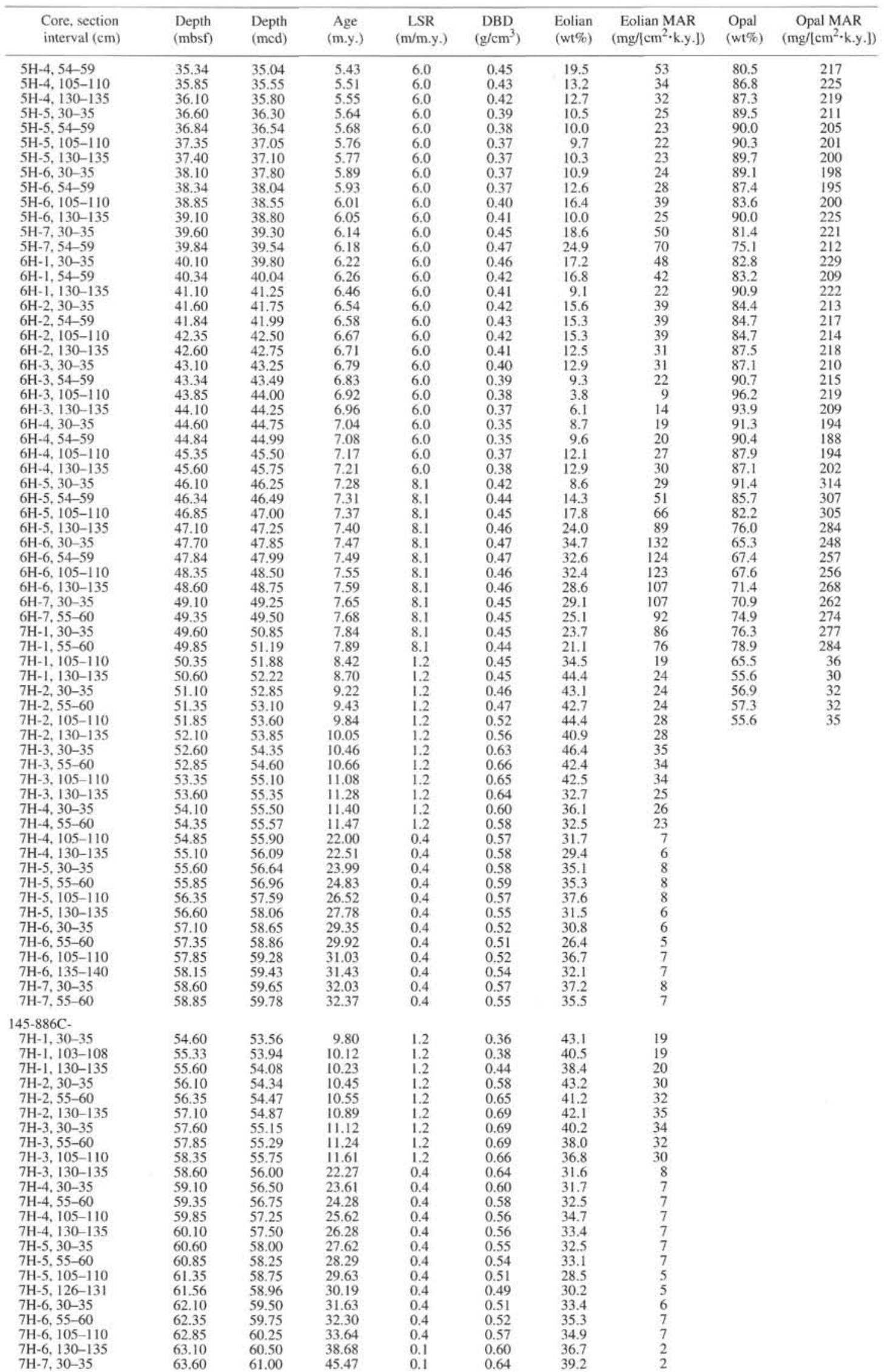


Table 1 (continued).

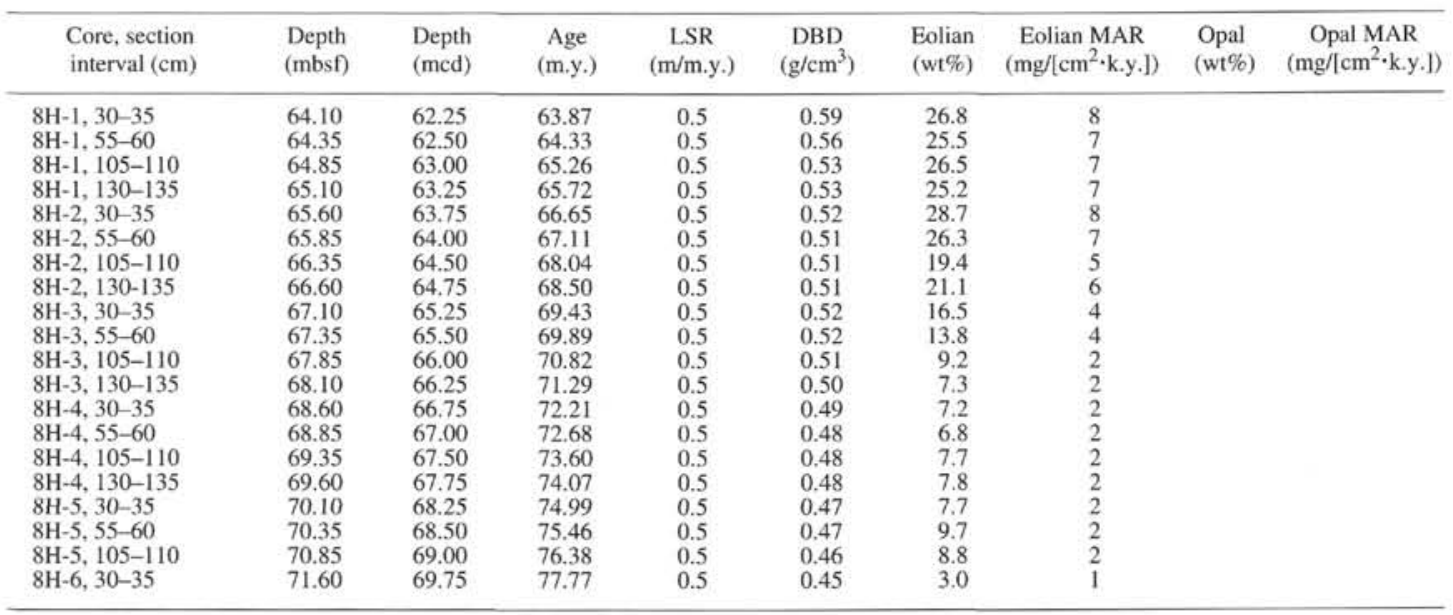

Note: $\mathrm{DBD}=$ dry bulk density, $\mathrm{LSR}=$ linear sedimentation rate, and MAR = mass accumulation rate.

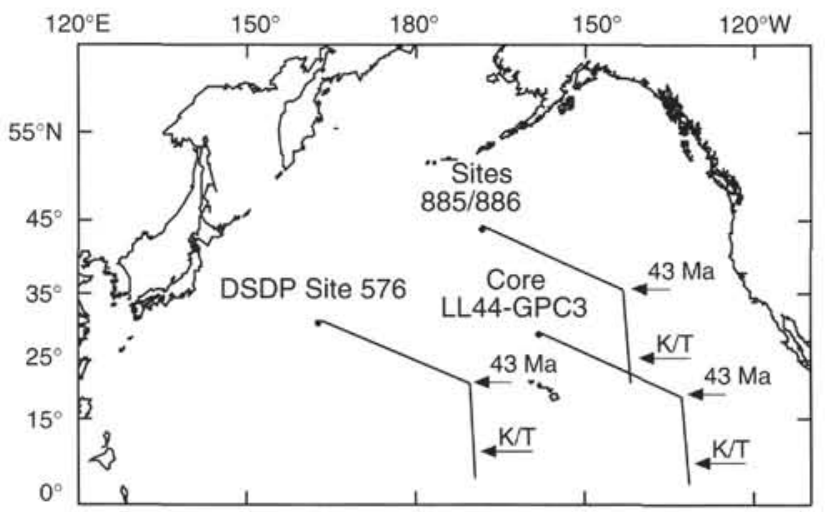

Figure 3. Present location of ODP Sites $885 / 886$, DSDP Site 576, and piston Core LL44-GPC3. Lines are pale-backtrack paths. Plate rotation model is from van Andel et al. (1975). K/T = Cretaceous/Tertiary boundary.

and increases to approximately $80 \%$ toward the bottom of Unit I (Fig. 6). Opaline silica is the dominant component in Unit II, occupying at least $80 \%$ of the sediment for most of the unit (Fig. 6). Below 46 mcd, opal becomes less important in the total sediment makeup (Fig. 6). No microfossils suitable for biostratigraphy were found below $53 \mathrm{mcd}$ (Rea, Basov, Janecek, Palmer-Julson, et al., 1993). Onboard measurements of DBD and porosity indicate an increase in DBD of $0.16-0.31$ $\mathrm{g} / \mathrm{cm}^{3}$ and a decrease in porosity of $6-11 \%$ between Samples $145-$ $885 \mathrm{~A}-6 \mathrm{H}-3,74 \mathrm{~cm}$ and $-6 \mathrm{H}-4,74 \mathrm{~cm}$, between $145-886 \mathrm{~B}-7 \mathrm{H}-2,69$ $\mathrm{cm}$ and $-7 \mathrm{H}-3,69 \mathrm{~cm}$, and between $886 \mathrm{C}-7 \mathrm{H}-1,109 \mathrm{~cm}$ and $-7 \mathrm{H}-2$, $69 \mathrm{~cm}$ (Rea, Basov, Janecek, Palmer-Julson, et al., 1993). Opaline silica-bearing sediments are usually characterized by lower DBD and higher porosity than opal-free sediments. Based on those two parameters, the transition from fossil-bearing to barren sediments is bracketed between $54 \mathrm{mcd}$ and $54.5 \mathrm{mcd}$. A visual examination of smearslides from samples in this interval shows the presence of some biogenic opal debris in samples shallower than $54.1 \mathrm{med}$ but none in samples below $54.3 \mathrm{mcd}$.

\section{Mass Accumulation Rates: the Time Frame}

The age model, based on the stratigraphic data (Table 2), is depicted as an age-depth plot in Figure 2A. The plot shows steep slopes in Units I and II, indicating fast sedimentation rates (Fig. 2B). Unit I extends back to approximately $3.55 \mathrm{Ma}$, whereas Unit II extends back to about $11 \mathrm{Ma}$. The LSRs between 0 and $2.6 \mathrm{Ma}$ average $5 \mathrm{~m} / \mathrm{m}$.y.,

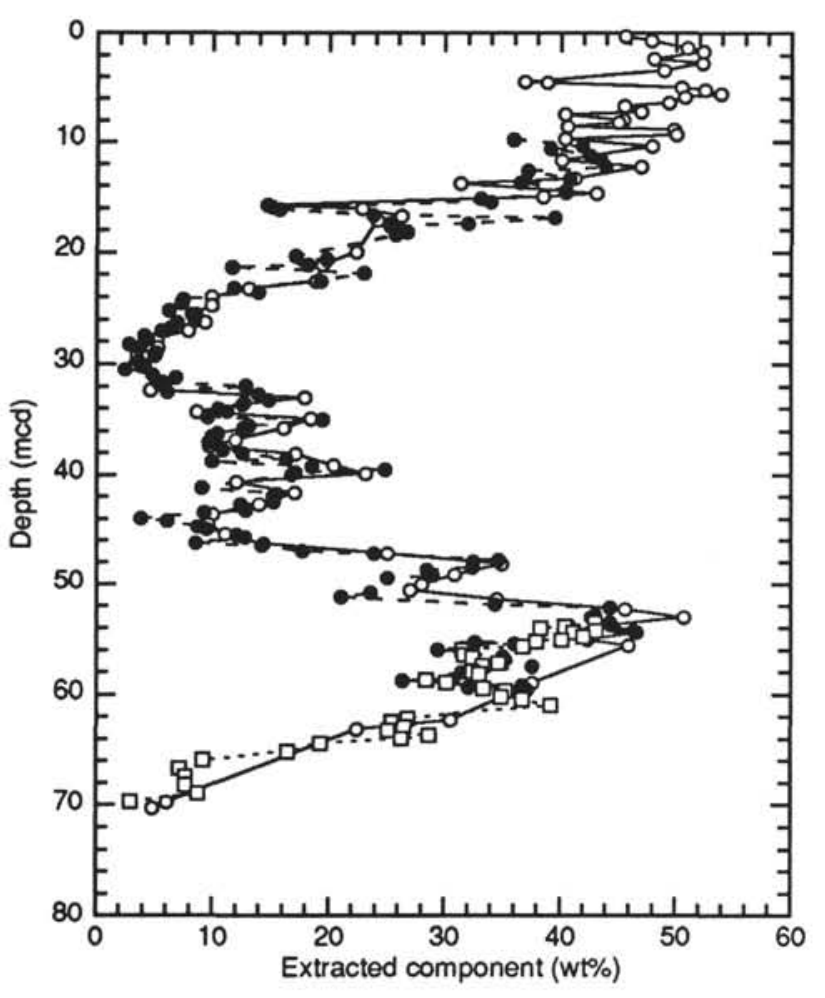

Figure 4. Abundance (in weight percent) of the extracted eolian component of sediments at Sites $885 / 886$. The record for Hole $885 \mathrm{~A}$ is represented by open circles connected by a solid line, the record for Hole $886 \mathrm{~B}$ is represented by solid circles connected by a long-dashed line, and the record for Hole $886 \mathrm{C}$ is represented by open squares connected by a short-dashed line. All samples were placed on a composite depth scale. Note excellent correspondence of records from different holes.

and increase to approximately $6.5 \mathrm{~m} / \mathrm{m}$.y. from 2.6 to $7.25 \mathrm{Ma}$ (Fig. 2B). There is a distinct decrease in LSR toward the bottom of Unit II, equivalent to the time interval between 8.5 and $11 \mathrm{Ma}$ (Fig. 2B). A break in the age-depth relationship at 55 mcd marks the boundary between Units II and III and may indicate a hiatus occurring between approximately 11 and $20 \mathrm{Ma}$ based on ${ }^{87} \mathrm{Sr} /{ }^{86} \mathrm{Sr}$ stratigraphy (Fig. 2A). A hiatus at this depth was suggested by Dickens et al. (this volume). Ichthyoliths allowed us to determine the age-depth relationship for 
Table 2. Stratigraphic control data, Sites $885 / 886$.

\begin{tabular}{|c|c|c|c|c|c|}
\hline \multicolumn{6}{|c|}{ Paleomagnetostratigraphy } \\
\hline Magnetic reversal & Core, section, interval $(\mathrm{cm})$ & $\begin{array}{l}\text { Depth } \\
\text { (mbsf) }\end{array}$ & $\begin{array}{l}\text { Depth } \\
\text { (mcd) }\end{array}$ & $\begin{array}{c}\text { Age } \\
\text { (m.y.) }\end{array}$ & Source \\
\hline $\begin{array}{l}\text { Brunhes/Matuyama } \\
\text { Termination Jaramillo } \\
\text { Onset Jaramillo } \\
\text { Termination Olduvai } \\
\text { Onset Olduvai } \\
\text { Matuyama/Gauss } \\
\text { Gauss/Gilbert } \\
\text { Termination C4n.1n } \\
\text { Onset C4n.2n } \\
\text { Termination C4An }\end{array}$ & & & $\begin{array}{r}4.88 \\
5.71 \\
6.20 \\
9.55 \\
10.52 \\
14.58 \\
23.75 \\
45.98 \\
51.25 \\
52.01\end{array}$ & $\begin{array}{l}0.780 \\
0.984 \\
1.049 \\
1.757 \\
1.983 \\
2.600 \\
3.553 \\
7.245 \\
7.892 \\
8.529\end{array}$ & $\begin{array}{l}1 \\
1 \\
1 \\
1 \\
1 \\
1 \\
1 \\
1 \\
1 \\
1\end{array}$ \\
\hline \multicolumn{6}{|c|}{ Biostratigraphy } \\
\hline \multicolumn{6}{|l|}{ Radiolarian event } \\
\hline $\begin{array}{l}\text { LO S. acquilonium } \\
\text { LO } S \text {. umiversus } \\
\text { LO L. heteroporos } \\
\text { FO C. davisiana davisiana } \\
\text { FO L. heteroporos } \\
\text { T S. delmontensis-S. peregrina } \\
\text { FO } S \text {, acquilonium } \\
\text { LO } L \text {. nipponica magnacornuta }\end{array}$ & $\begin{array}{l}145-885 \mathrm{~A}-1 \mathrm{H}-1,115 \text { and }-1 \mathrm{H}-2,115 \\
145-885 \mathrm{~A}-1 \mathrm{H}-1,115 \text { and }-1 \mathrm{H}-2,115 \\
145-885 \mathrm{~A}-1 \mathrm{H}-1,115 \text { and }-1 \mathrm{H}-2,115 \\
145-885 \mathrm{~A}-2 \mathrm{H}-5,115 \text { and }-2 \mathrm{H}-6,115 \\
145-885 \mathrm{~A}-5 \mathrm{H}-2,115 \text { and }-5 \mathrm{H}-3,115 \\
145-885 \mathrm{~A}-5 \mathrm{H}-5,115 \text { and }-5 \mathrm{H}-6,115 \\
145-885 \mathrm{~A}-5 \mathrm{H}-6,115 \text { and }-6 \mathrm{H}-1,115 \\
145-885 \mathrm{~A}-6 \mathrm{H}-1,115 \text { and }-6 \mathrm{H}-2,115\end{array}$ & \begin{tabular}{|l}
$1.15-2.65$ \\
$1.15-2.65$ \\
$1.15-2.65$ \\
$11.75-13.25$ \\
$35.75-37.25$ \\
$40.25-41.75$ \\
$41.75-43.75$ \\
$43.75-45.25$
\end{tabular} & $\begin{array}{c}1.54-3.67 \\
1.54-3.67 \\
6.56-8.10 \\
14.86-16.91 \\
41.83-43.78 \\
47.35-49.34 \\
49.34-51.57 \\
51.57-53.24\end{array}$ & $\begin{array}{l}0.4 \\
0.55 \\
1.7 \\
2.9 \\
6.5 \\
7.55 \\
7.72 \\
8.8\end{array}$ & $\begin{array}{l}2 \\
2 \\
2 \\
2 \\
2 \\
2 \\
2\end{array}$ \\
\hline $\begin{array}{l}\text { LO } S \text {. acquilonium } \\
\text { LO S. universus } \\
\text { LO L. heteroporos } \\
\text { FO C. davisiana davisiana } \\
\text { FO L. heteroporos } \\
\text { T S. delmontensis-S. peregrina } \\
\text { FO S. acquilonium } \\
\text { LO L. nipponica magnacornuta }\end{array}$ & $\begin{array}{l}145-886 \mathrm{C}-1 \mathrm{H}-1,114 \text { and }-1 \mathrm{H}-2,114 \\
145-886 \mathrm{C}-1 \mathrm{H}-2,114 \text { and }-1 \mathrm{H}-3,114 \\
145-886 \mathrm{C}-1 \mathrm{H}-4,114 \text { and }-2 \mathrm{H}-1,114 \\
145-886 \mathrm{C}-3 \mathrm{H}-1,114 \text { and }-3 \mathrm{H}-2,114 \\
145-886 \mathrm{C}-5 \mathrm{H}-3,98 \text { and }-6 \mathrm{H}-1,114 \\
145-886 \mathrm{C}-6 \mathrm{H}-3,112 \text { and }-6 \mathrm{H}-4,114 \\
145-886 \mathrm{C}-6 \mathrm{H}-4,114 \text { and }-6 \mathrm{H}-5,114 \\
145-886 \mathrm{C}-6 \mathrm{H}-5,114 \text { and }-6 \mathrm{H}-\mathrm{CC}\end{array}$ & \begin{tabular}{|c|}
$1.14-2.64$ \\
$2.64-4.14$ \\
$5.64-7.94$ \\
$17.44-18.94$ \\
$39.28-45.94$ \\
$48.92-50.44$ \\
$50.44-51.94$ \\
$51.94-54.3$
\end{tabular} & $\begin{array}{c}1.14-2.64 \\
2.64-14 \\
5.84-9.30 \\
15.29-16.99 \\
37.9-44.63 \\
47.51-49.04 \\
49.04-50.54 \\
50.54-52.90\end{array}$ & $\begin{array}{l}0.4 \\
0.55 \\
1.7 \\
2.9 \\
6.5 \\
7.55 \\
7.72 \\
8.5\end{array}$ & $\begin{array}{l}2 \\
2 \\
2 \\
2 \\
2 \\
2 \\
2\end{array}$ \\
\hline \multicolumn{6}{|c|}{ Sr-isotope stratigraphy } \\
\hline & $\begin{array}{l}145-885 \mathrm{~A}-6 \mathrm{H}-1,125-130 \\
145-885 \mathrm{~A}-6 \mathrm{H}-2,50-55 \\
145-885 \mathrm{~A}-6 \mathrm{H}-4,50-55 \\
145-885 \mathrm{~A}-6 \mathrm{H}-4,125-130 \\
145-885 \mathrm{~A}-6 \mathrm{H}-5,50-55 \\
145-885 \mathrm{~A}-7 \mathrm{H}-\mathrm{CC}^{+}\end{array}$ & $\begin{array}{l}43.85 \\
44.60 \\
47.60 \\
48.35 \\
49.10 \\
52.10\end{array}$ & $\begin{array}{l}51.69 \\
52.64 \\
55.29 \\
55.90 \\
59.68 \\
70.70\end{array}$ & $\begin{array}{r}5.7 \\
5.9 \\
21.3 \\
19.4 \\
30.2 \\
79.0\end{array}$ & $\begin{array}{l}3 \\
3 \\
3 \\
3 \\
3 \\
3\end{array}$ \\
\hline & $\begin{array}{l}145-886 \mathrm{~B}-7 \mathrm{H}-2,47-52 \\
145-886 \mathrm{~B}-7 \mathrm{H}-3,135-140 \\
145-886 \mathrm{~B}-7 \mathrm{H}-4,47-52 \\
145-886 \mathrm{~B}-7 \mathrm{H}-4,125-130 \\
145-886 \mathrm{~B}-7 \mathrm{H}-4,135-140 \\
145-886 \mathrm{~B}-7 \mathrm{H}-5,120-125 \\
145-886 \mathrm{~B}-7 \mathrm{H}-6,140-145 \\
145-886 \mathrm{~B}-7 \mathrm{H}-7,47-52 \\
145-886 \mathrm{~B}-7 \mathrm{H}-7,64-69\end{array}$ & $\begin{array}{l}51.27 \\
53.67 \\
54.27 \\
55.05 \\
55.17 \\
56.52 \\
58.22 \\
58.77 \\
58.94\end{array}$ & $\begin{array}{l}53.02 \\
55.37 \\
55.55 \\
56.05 \\
56.14 \\
57.87 \\
59.46 \\
59.74 \\
59.82\end{array}$ & $\begin{array}{r}6.5 \\
11.3 \\
11.1 \\
24.0 \\
21.5 \\
27.8 \\
30.7 \\
31.3 \\
31.2\end{array}$ & $\begin{array}{l}3 \\
3 \\
3 \\
3 \\
3 \\
3 \\
3 \\
3 \\
3 \\
3\end{array}$ \\
\hline & $\begin{array}{l}145-886 \mathrm{C}-6 \mathrm{H}-4,135-140 \\
145-886 \mathrm{C}-6 \mathrm{H}-7,60-65 \\
145-886 \mathrm{C}-7 \mathrm{H}-2,135-140 \\
145-886 \mathrm{C}-7 \mathrm{H}-3,11-16 \\
145-886 \mathrm{C}-7 \mathrm{H}-3,135-140 \\
145-886 \mathrm{C}-7 \mathrm{H}-4,135-140 \\
145-886 \mathrm{C}-7 \mathrm{H}-5,120-125 \\
145-886 \mathrm{C}-7 \mathrm{H}-6,10-15 \\
145-886 \mathrm{C}-8 \mathrm{H}-1,135-140 \\
145-886 \mathrm{C}-8 \mathrm{H}-2,10-15 \\
145-886 \mathrm{C}-8 \mathrm{H}-4,30-35 \\
145-886 \mathrm{C}-8 \mathrm{H}-4,45-50 \\
145-886 \mathrm{C}-8 \mathrm{H}-4,135-140 \\
145-886 \mathrm{C}-8 \mathrm{H}-5,120-125 \\
145-886 \mathrm{C}-8 \mathrm{H}-6,75-80\end{array}$ & $\begin{array}{l}50.30 \\
54.40 \\
57.15 \\
57.41 \\
58.65 \\
60.17 \\
61.52 \\
61.90 \\
65.15 \\
65.40 \\
68.60 \\
68.75 \\
69.60 \\
71.00 \\
72.05\end{array}$ & $\begin{array}{l}48.90 \\
53.00 \\
54.90 \\
55.04 \\
56.05 \\
57.57 \\
58.92 \\
59.30 \\
63.30 \\
63.55 \\
66.75 \\
66.90 \\
67.75 \\
69.15 \\
70.20\end{array}$ & $\begin{array}{r}5.8 \\
6.1 \\
11.0 \\
11.0 \\
21.0 \\
28.5 \\
34.0 \\
32.8 \\
65.0 \\
33.6 \\
68.5 \\
71.5 \\
72.5 \\
76.5 \\
74.5\end{array}$ & $\begin{array}{l}3 \\
3 \\
3 \\
4 \\
3 \\
3 \\
3 \\
4 \\
3 \\
4 \\
4 \\
4 \\
3 \\
3 \\
4\end{array}$ \\
\hline Ir anomaly & $145-886 \mathrm{C}-8 \mathrm{H}-1,130$ and $-8 \mathrm{H}-1,145$ & $65.1-65.25$ & $63.25-63.40$ & 66 & 5 \\
\hline $\mathrm{Ar} / \mathrm{Ar}$ dating & Basement & 52.30 & 70.95 & 80 & 6 \\
\hline
\end{tabular}

Notes: $\mathrm{med}=$ meters composite depth. $\mathrm{LO}=$ last occurrence, $\mathrm{FO}=$ first occurrence, $\mathrm{T}=$ species transition. $1=$ Rea. Basov, et al. $(1993) ; 2=\mathrm{Morley}$ and Nigrini $($ this volume); $3=$ Ingram (this volume); $4=$ this paper; $5=\mathrm{Kyte}$ and Zhou (this volume); $6=\mathrm{Keller}$ and Duncan (this volume), $*=$ this sample is listed as $145-885 \mathrm{~A}-7 \mathrm{H}-\mathrm{CC}$. However, Core $7 \mathrm{H}$ has no core catcher. We assume this sample is $145-885 \mathrm{~A}-6 \mathrm{H}-\mathrm{CC}$.

the time interval between approximately 20 and $34 \mathrm{Ma}$, equivalent to the depth interval between 56 to 60 mcd (Fig. 2A). The LSRs between $\sim 34$ and $63 \mathrm{Ma}$, represented by $1.5 \mathrm{~m}$ of sediments and a $0.75-\mathrm{m}$ core gap (Dickens et al., this volume), are low, and occurrences of hiatuses are likely (Fig. 2A). However, the possibility of resolving this part of the sediment record using the seawater $\mathrm{Sr}$ - isotope curve is small because ${ }^{87} \mathrm{Sr} /{ }^{86} \mathrm{Sr}$ ratios do not vary much in this time interval. The difference in slope in the age-depth plot between Units I and II compared with Subunit IIIA attests to biogenous sedimentation as the driving force in the rate of sedimentation (Fig 2A). In Subunit IIIB, however, hydrothermal sedimentation may be the controlling factor. Sedimentation rates between the $\mathrm{K} / \mathrm{T}$ boundary and the basement average $0.5 \mathrm{~m} / \mathrm{m}$.y. An exponential increase in LSR toward the basement is predicted by the hydrothermal activity model for the first 15 m.y. (Dickens and Owen, this volume). An exponential best fit curve through the ${ }^{87} \mathrm{Sr} /{ }^{86} \mathrm{Sr}$ ages in Core $886 \mathrm{C}-8 \mathrm{H}$ yields ages that are $1.8-2.2 \mathrm{~m}$.y. younger than those obtained by linear regression between the $\mathrm{K} / \mathrm{T}$ boundary and the basement. There is no significant dif- 


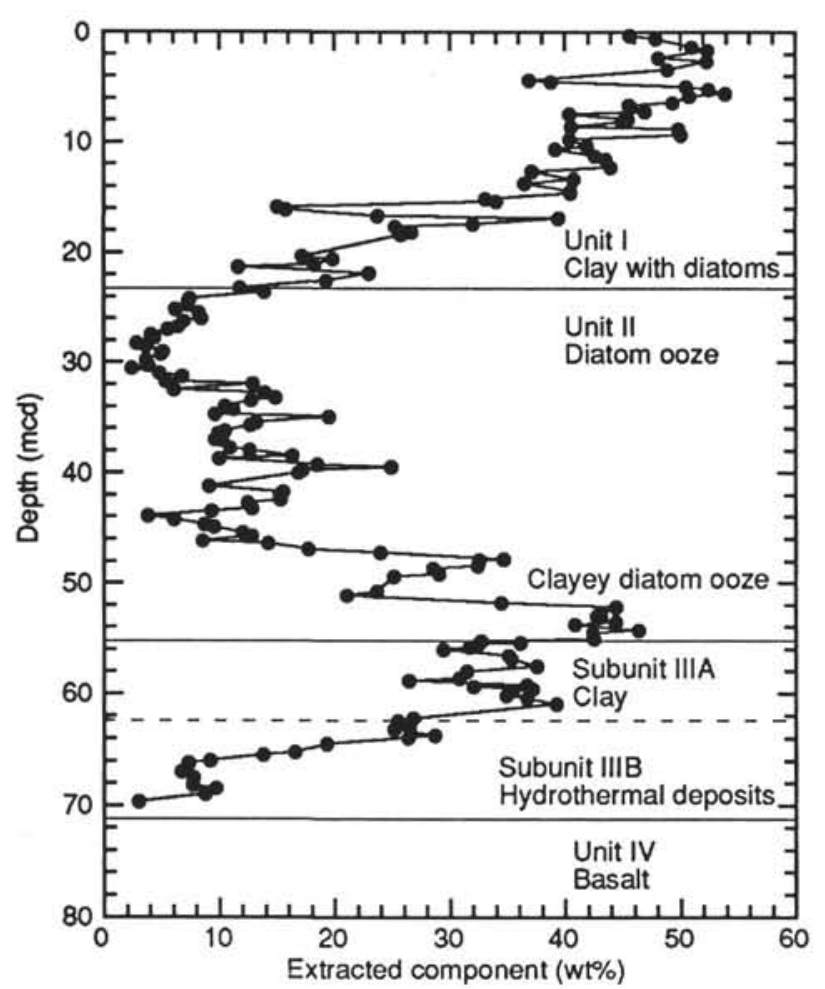

Figure 5. Record of eolian abundances at Sites $885 / 886$ with lithostratigraphy on right-hand side. The eolian record has been assembled from data obtained in the top $10.25 \mathrm{mcd}$ in Hole $885 \mathrm{~A}$, between 10.25 and $60 \mathrm{mcd}$ in Hole 886B, and between $60 \mathrm{mcd}$ and basement (at $70.95 \mathrm{mcd}$ ) in Hole 886C. Lithologic units are from Rea, Basov, Janecek, Palmer-Julson, et al. (1993), as modified by Dickens et al. (this volume).

ference in the eolian MAR. In view of the uncertainties of the ${ }^{87} \mathrm{Sr} /{ }^{86} \mathrm{Sr}$ stratigraphy determined on ichthyoliths (see above) and the sampling resolution of the fish teeth, we prefer the linear interpolation approach.

Several unexpected values in the LSRs are emphasized in Figure 2. Suspect high LSRs occur between 0.984 and $1.049 \mathrm{Ma}$, between 2.6 and $3.553 \mathrm{Ma}$, and between 7.245 and $7.892 \mathrm{Ma}$. These values are a consequence of closely spaced "age-picks." Although not necessarily wrong, these high LSRs lead to anomalously high MARs compared to MARs calculated from LSRs averaged over more widely spaced "age-picks."

\section{Eolian Mass Accumulation Rates}

Eolian fluxes were low, that is less than $10 \mathrm{mg} /\left(\mathrm{cm}^{2} 148 \mathrm{k} . \mathrm{y}\right.$.) for most of the history of the sites (Fig. 7). A slight increase in eolian MARs at the end of the Cretaceous is probably the result of LSR averaging and not indicative of paleoclimate in the Late Cretaceous and Paleocene. Eocene sediments occur in negligible amounts. During the Oligocene and earliest Miocene, eolian sediments were deposited, but fluxes remained low (10 mg/[ $\left.\left.\mathrm{cm}^{2} 148 \mathrm{k.y}.\right]\right)$ (Fig. 7). The first eolian deposition of note occurs at approximately $11 \mathrm{Ma}$ (Figs. 7 and 8). Eolian accumulation for most of the late Miocene fluctuates around $30 \mathrm{mg} /\left(\mathrm{cm}^{2} 148 \mathrm{k} . \mathrm{y}\right.$.). An exception in this trend is the sudden spike in eolian MARs between 7.8 and 7.2 Ma (Fig. 8), a consequence in part of the presence of a large eolian component but probably caused more so by elevated LSRs. Eolian fluxes are very low (less than $10 \mathrm{mg} /\left[\mathrm{cm}^{2}\right.$ 148 k.y.]) in the early Pliocene, at the high tide of the "Diatom Dump" (Fig. 8). At $\sim 3.5 \mathrm{Ma}$, fluxes increased rapidly to reach maxima in excess of $120 \mathrm{mg} /\left(\mathrm{cm}^{2} 148 \mathrm{k} . \mathrm{y}\right.$.) between 2.6 and $2.0 \mathrm{Ma}$. Fluxes in the younger sediments vary from $\sim 90$ to $100 \mathrm{mg} /\left(\mathrm{cm}^{2} 148 \mathrm{k} . \mathrm{y}\right.$.) in the early Pleistocene and from $\sim 130-150 \mathrm{mg} /\left(\mathrm{cm}^{2} 148 \mathrm{k} . \mathrm{y}\right.$.) for the last $1 \mathrm{~m} . \mathrm{y}$.

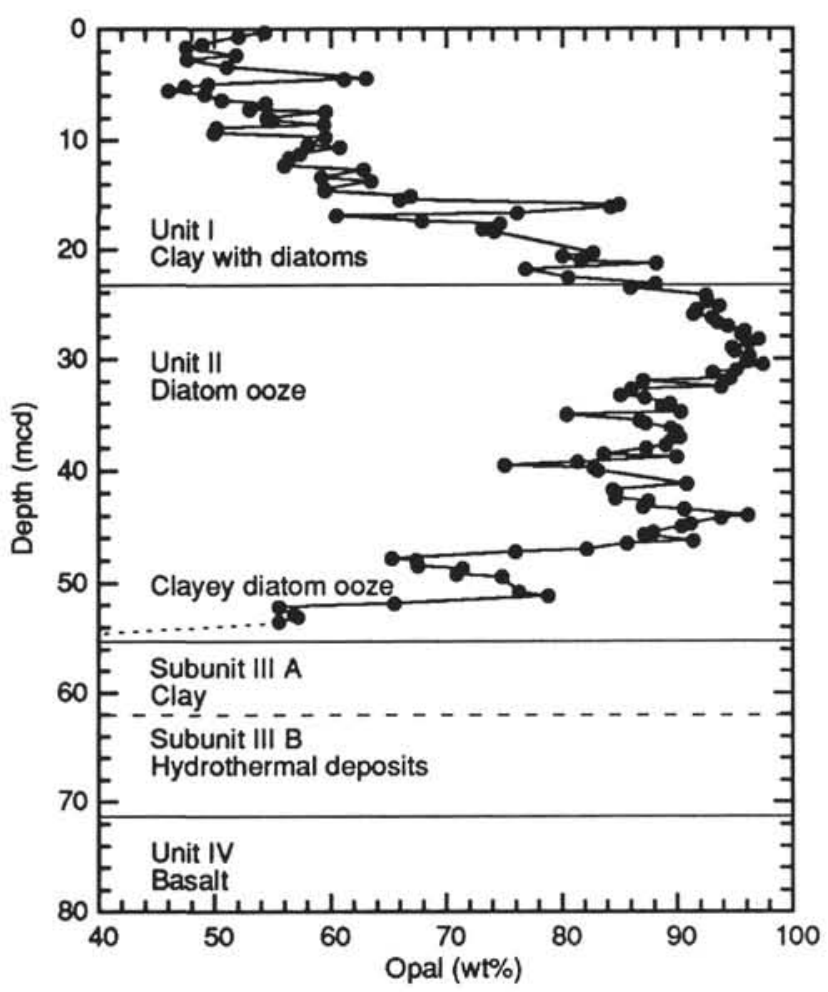

Figure 6. Record of opal abundances at Sites $885 / 886$. The opal record has been assembled from data obtained in the top $10.25 \mathrm{mcd}$ of Hole $885 \mathrm{~A}$, and between 10.25 and $55 \mathrm{mcd}$ of Hole 886B. The sediment column is barren of siliceous microfossils below $\sim 54 \mathrm{mcd}$, (i.e., in Subunits IIIA and IIB). Lithologic units are from Rea, Basov, Janecek, Palmer-Julson, et al. (1993), as modified by Dickens et al. (this volume).

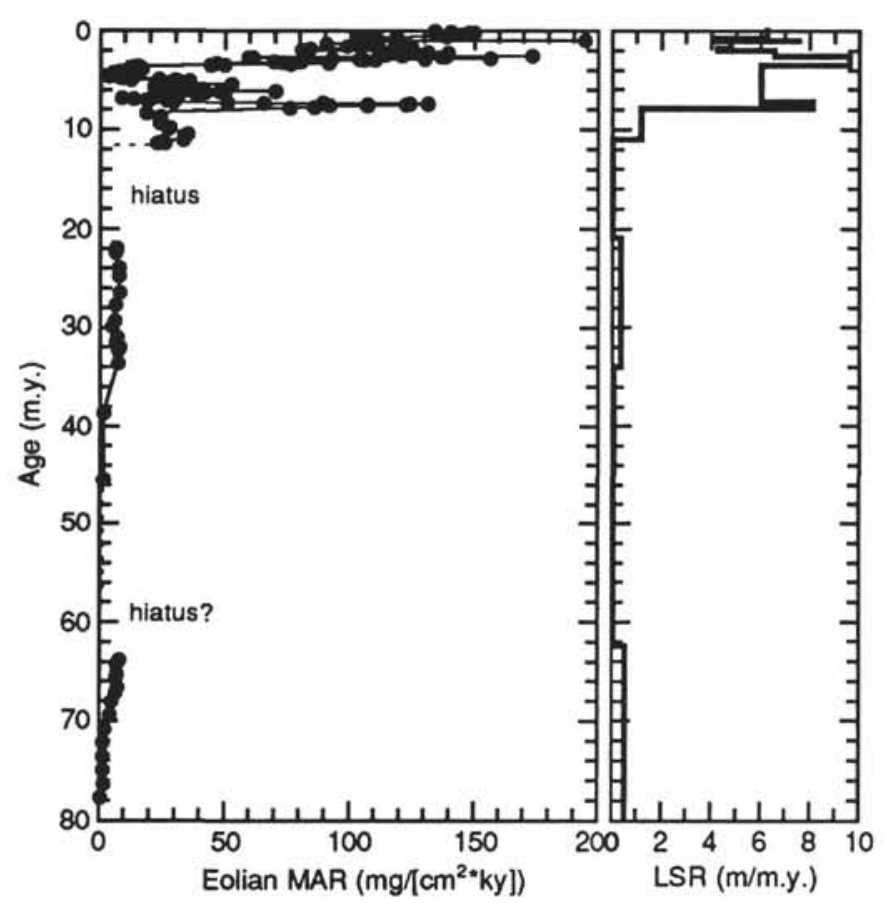

Figure 7. Mass accumulation rates (MAR) of eolian sediment at Sites 885/886 during the past 80 m.y. Linear sedimentation rates (LSR) shown for reference. 
Table 3. Fish teeth Sr-isotopic results.

\begin{tabular}{|c|c|c|c|c|c|}
\hline $\begin{array}{l}\text { Core, section, } \\
\text { interval }(\mathrm{cm})\end{array}$ & $\begin{array}{l}\text { Depth } \\
\text { (mbsf) }\end{array}$ & $\begin{array}{l}\text { Depth } \\
\text { (mcd) }\end{array}$ & Notes & $\begin{array}{l}\text { Visible } \\
\text { oxides }\end{array}$ & ${ }^{87} \mathrm{Sr} /{ }^{86} \mathrm{Sr} \pm 2 \mathrm{~s}$ \\
\hline \multicolumn{6}{|l|}{$145-886 \mathrm{C}$ - } \\
\hline $6 \mathrm{H}-4,100-105$ & 50.30 & 48.90 & 2 teeth & No & $0.708949 \pm 45$ \\
\hline $6 \mathrm{H}-7,60-65$ & 54.40 & 53.00 & 8 teeth & No & $0.708926 \pm 24$ \\
\hline $7 \mathrm{H}-3,11-16$ & 57.41 & 55.04 & 7 teeth & No & $0.708846 \pm 13$ \\
\hline $7 \mathrm{H}-6,10-15$ & 61.90 & 59,30 & 7 teeth & No & $0.707965 \pm 17$ \\
\hline $8 \mathrm{H}-2,10-15$ & 65.40 & 63.55 & 8 tiny teeth & Yes & $0.707939 \pm 17$ \\
\hline $8 \mathrm{H}-4,30-35$ & 68.60 & 66.75 & I big tooth & Yes & $0.707749 \pm 15$ \\
\hline $8 \mathrm{H}-4,45-50$ & 68.75 & 66.90 & 4 teeth & Yes & $0.707698 \pm 15$ \\
\hline $8 \mathrm{H}-6 \mathrm{a}, 75-80$ & 72.05 & 70.20 & 1 big bored tooth & Yes & $0.707617 \pm 20$ \\
\hline $8 \mathrm{H}-6 \mathrm{~b}, 75-80$ & 72.05 & 70.20 & 9 tiny teeth & Yes & $0.707809 \pm 17$ \\
\hline \multicolumn{6}{|l|}{ NBS 987} \\
\hline (analyzed twice) & & & & & $0.710246 \pm 17$ \\
\hline \multicolumn{6}{|l|}{ Long-term } \\
\hline NBS 987 average & & & & & $0.710248 \pm 18$ \\
\hline
\end{tabular}

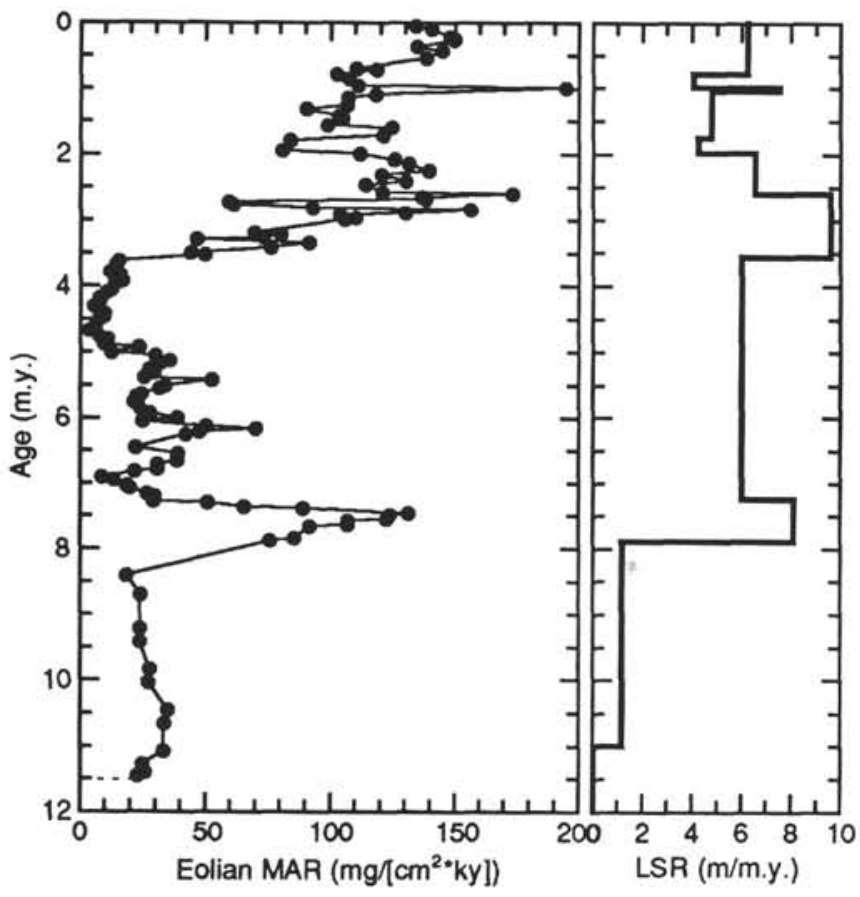

Figure 8. MAR of eolian sediment at Sites $885 / 886$ during the past 11 m.y. Eolian fluxes increased markedly in the late Pliocene, corresponding to the onset of Northern Hemisphere glaciation. Increased fluxes between 2.6 and $3.5 \mathrm{Ma}$ and between 7.2 and $7.8 \mathrm{Ma}$ are probably artifacts of the linear sedimentation rate. LSR shown for reference.

\section{Opal Mass Accumulation Rates}

The oldest sediments with an identifiable siliceous microfossil assemblage are approximately $9 \mathrm{~m}$.y. old (Joe Morley, pers. comm., 1994). Based on changes in DBD and porosity of the sediment, the visual examination of smearslides (see above), and our age model, which is partly based on ichthyolith-ages, we determine the age of the oldest opal-bearing sediment between 10 and $10.5 \mathrm{Ma}$ (Fig. 9). Opal deposition remained low during the first $2 \mathrm{~m}$.y but it was well underway at $8 \mathrm{Ma}$. The abrupt rise in opal MAR at $8 \mathrm{Ma}$ may be an artifact of the exceptional LSRs mentioned above (Fig. 9). The details in the opal record are LSR driven. The failure to distinguish the interval of increased silica deposition clearly between approximately 6 and 3 $\mathrm{Ma}$, as seen in all other Leg 145 sites, (especially the somewhat puzzling low accumulation between 5 and $3.5 \mathrm{Ma}$ ) may be caused by the choice of the "master section" for the composite depth for this interval. Dickens et al. (this volume) suggest that the composite depth

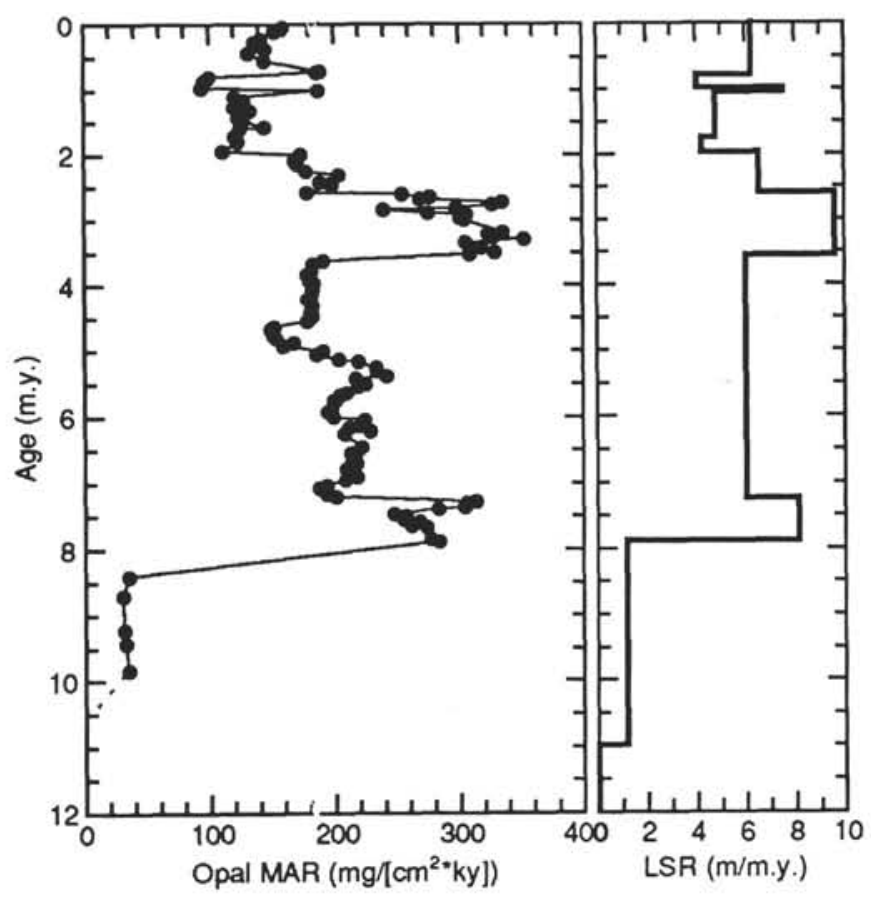

Figure 9. MAR of opal at Sites 885/886 during the past 11 m.y. Opal fluxes during the Pliocene "silica dump" are 1.5 to 2 times higher than fluxes during the Pleistocene. The height of the flux between 2.6 and $3.5 \mathrm{Ma}$ and the rapid increase in opal flux at $7.8 \mathrm{Ma}$ are artifacts of the LSR, shown for reference.

at about 30 mcd may be $\sim 1.5 \mathrm{~m}$ too short because of compression caused by drilling through soft diatom ooze. However, the overall picture clearly shows $1.5-2$ times higher opal fluxes during the late Miocene and early Pliocene than in the period after 2.6-2 Ma. There may be a stepwise(?) increase in opal MAR at about 1 Ma from 120 to $160 \mathrm{mg} /\left(\mathrm{cm}^{2} 148 \mathrm{k} . \mathrm{y}\right.$. $)$ in the late Pleistocene.

\section{DISCUSSION}

The record of eolian fluxes at Sites $885 / 886$ at a location that is $12^{\circ}-14^{\circ} \mathrm{N}$ of DSDP Site 576 and piston Core LL44-GPC3 (Fig. 3) provides an excellent addition to the knowledge of paleoclimate gathered from those well-studied records.

As in Sites 885/886, much of the time scale for Core LL44-GPC3 has been derived based on different, uncommon tools, whose use have lead to different interpretations. In presenting the depositional history for this red clay core we have used the time scale published by Janecek and Rea (1983). The stratigraphy is based largely on fish teeth (Doyle and Riedel, 1979) along with magnetic reversal stratigraphy down to the Matuyama/Gauss boundary (Prince et al., 1980). Leinen and her co-workers (including Rea et al., 1985; Doh et al., 1988; and Leinen, 1989) show a somewhat different stratigraphy, also based on ichthyoliths. This version has accumulation peaks in the lower and middle Miocene part of the section. Kyte et al. (1993) have generated a third age-model for this core based on the assumption that cobalt accumulates at a constant rate in the sediments throughout the Tertiary, and on the discovery of the Ir anomaly associated with the Cretaceous/Tertiary boundary at a depth of $20.6 \mathrm{mbsf}$ (Kyte and Wasson, 1986). The presence of three age models in the literature for the same core points out the need for a reliable stratigraphic tool with which to date the pelagic clays of the abyssal oceans.

All three sites have records which extend back into the Late Cretaceous. During the Late Cretaceous and the Paleocene eolian MARs at DSDP Site 576 and in Core LL44-GPC3 were low (Fig. 10), corresponding to warm and wet climates (Janecek, 1985). Furthermore, 

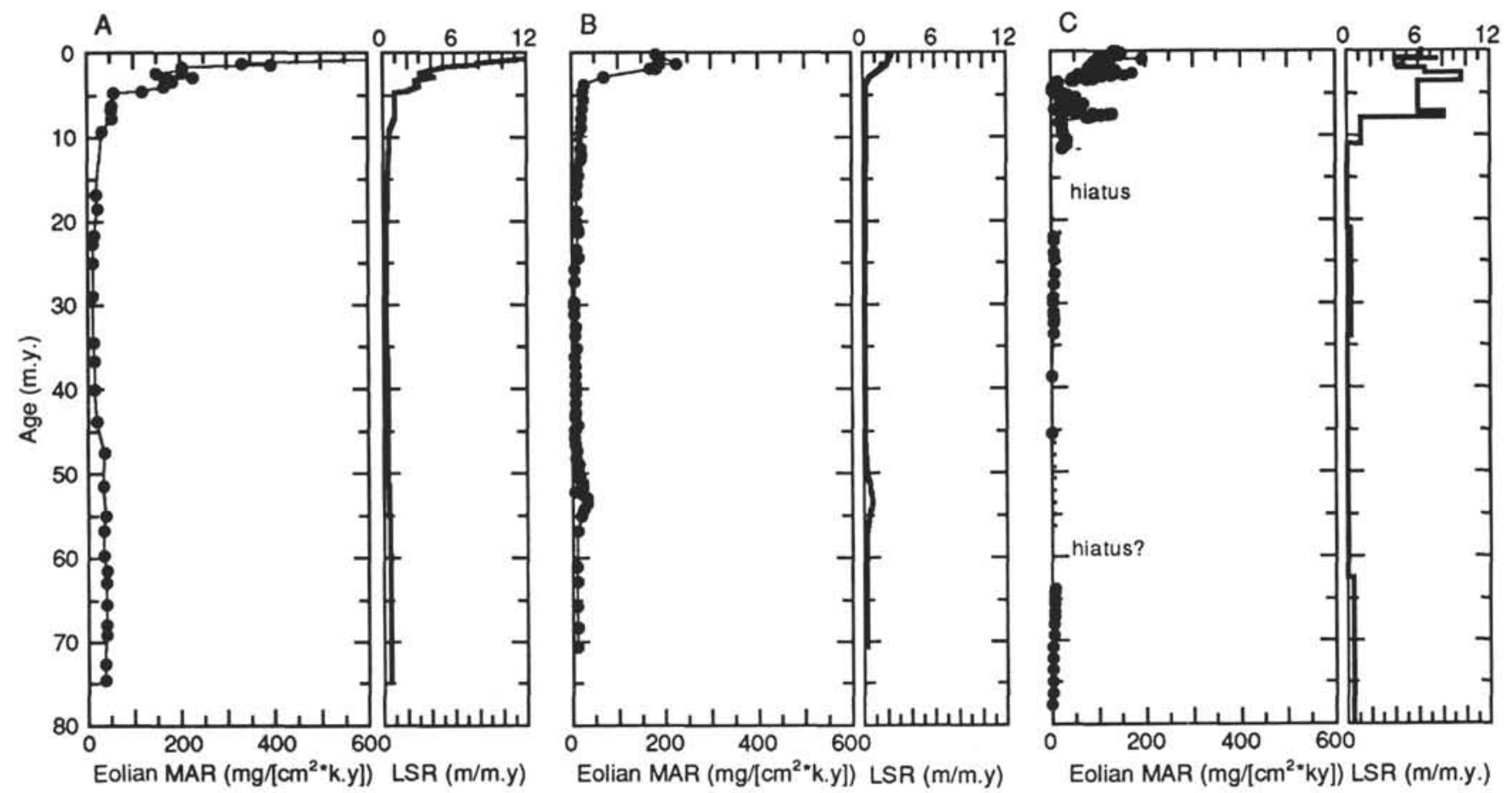

Figure 10. A. MAR of eolian sediment at DSDP Site $576\left(32^{\circ} \mathrm{N}, 164^{\circ} \mathrm{E}\right)$ during the past 75 m.y. (Janecek, 1985); B. MAR in piston Core LL44-GPC3 $\left(30^{\circ} \mathrm{N}\right.$, $158^{\circ} \mathrm{W}$ ) during the past $70 \mathrm{~m} . \mathrm{y}$. (Janecek and Rea, 1983); C. MAR at Sites 885/886. LSR shown for reference.

during the middle and late Eocene, the records show a further decrease in eolian MARs (Fig. 10). This decrease was interpreted as the result of a more humid climate in the eolian source region and/or the passage of those sites from one wind belt to another (Leinen and Heath, 1981; Janecek and Rea, 1983; Rea, 1994). Our results show no exception: accumulation during the Cretaceous is low, and (nearly) nonexistent during the later part of the Paleocene and during the Eocene. Because ODP Sites $885 / 886$ are situated north of the other sites, and because the Pacific Plate moved northward (Fig. 3), the movement of Sites $885 / 886$ from one wind belt to another should have occurred earlier. The record at Sites $885 / 886$ does not provide evidence for this event. Low accumulation rates at DSDP Site 576 (Janecek, 1985) during the Oligocene contrast with our results. Higher eolian fluxes during the time interval between $\sim 20$ and 34 Ma suggest drier conditions in the source area. The onset of this interval may be coincident with the appearance of ice-rafted debris in the Southern Ocean at about $34 \mathrm{Ma}$ and glaciological evidence for ice cover on Antarctica (Crowley and North, 1991). The age resolution provided by the fish teeth does not allow precise determination of the onset of this interval. The beginning of the Neogene is characterized by a doubling of the eolian accumulation (from very low to low) in Core LL44-GPC3 (Janecek and Rea, 1985) and at DSDP Site 576. This increase is thought to reflect the initiation of deposition from the westerlies at those sites as they moved under its influence (Janecek and Rea, 1985). If a similar increase in flux is present at Sites $885 / 886$, it remains unresolved within the resolution of the $\mathrm{Sr}$-isotope stratigraphy.

Eolian accumulation increases at $11 \mathrm{Ma}$, shortly before sediments begin to contain microfossils. Accumulation of the biogenic silica increases rapidly after $8 \mathrm{Ma}$, which would be over $1 \mathrm{~m}$.y. earlier than at the other Leg 145 sites, in which the kick off to the "Diatom Dump" occurs at 6-7 Ma (Rea and Snoeckx, this volume). An earlier onset of increased silica deposition may reflect the sensitivity of a marginal area to changes in and expansion of the high-productivity zone of the North Pacific. It is clear that a silica shift did occur at Sites 885/886 and although fluxes are smaller than at the other Leg 145 sites, they signify at least a fivefold increase compared with older sediments and $1.5-2$ times the accumulation in younger sediments.

The flux of the windblown sediments increases from $3.5 \mathrm{Ma}$ on to reach the highest eolian MARs during the late Pliocene and Pleistocene. A similar pattern was observed in Core LL44-GPC3 (Janecek and Rea, 1985) and at DSDP Site 576 (Janecek, 1985); it reflects the drying of the Asian source region before and after the onset of Northern Hemisphere glaciation at 2.6 Ma.

\section{CONCLUSIONS}

The sediment column of Sites 885/886 records the history of eolian deposition for much of the Cenozoic and latest Late Cretaceous. The record contains hiatuses between 11 and $20 \mathrm{Ma}$ and probably also in the Eocene and Paleocene.

Eolian fluxes were low in the Late Cretaceous and early Cenozoic as a consequence of the humid conditions thought to have prevailed at that time.

The flux of windblown sediments during the Oligocene reflects the drier climate conditions in the source area. The increased aridity is coincident with the expansion(?) of Antarctic glaciation and a general cooling and drying of the Northern Hemisphere.

The "Diatom Dump," an interval of increased opal accumulation in the late Miocene to middle Pliocene, extends areally to Sites $885 / 886$. Although fluxes are smaller than at the other Leg 145 sites, they signify a two- to fivefold increase to fluxes before and after the event.

A fivefold increase in eolian MARs beginning at 3.5 Ma testifies to the arid conditions that dominated continental climate at the onset of Northern Hemisphere glaciation.

\section{ACKNOWLEDGMENTS}

We thank everyone on Leg 145 for the company and the learning experience during the cruise. This manuscript was reviewed by William Balsam and John King whose useful suggestions greatly 
improved this manuscript. We also like to acknowledge the help of Joe Morley with biostratigraphic data. We also thank Karen Boven, Angela Walker, and Pamela Warner for help in the lab. This research was supported by the U.S. Science Support Program of the Joint Oceanographic Institutions.

\section{REFERENCES}

Bertram, C.J., Elderfield, H., Aldridge, R.J., and Conway-Morris, S., 1992. ${ }^{87} \mathrm{Sr} /{ }^{86} \mathrm{Sr},{ }^{143} \mathrm{Nd} /{ }^{144} \mathrm{Nd}$, and REE's in Silurian phosphatic fossils. Earth Planet. Sci. Lett., 113:239-249.

Cande, S.C., and Kent, D.V., 1992. A new geomagnetic polarity time scale for the Late Cretaceous and Cenozoic. J. Geophys. Res., 97:13917-13951.

Crowley, T.J., and North, G.R., 1991. Paleoclimatology: Oxford Monographs on Geology and Geophysics: New York (Oxford Univ. Press).

Doh, S.-J., King, J.W., and Leinen, M., 1988. A rock-magnetic study of giant piston core LL4-GPC3 from the central North Pacific and its paleoceanographic implications. Paleoceanography, 3:89-111.

Dole, P.S., and Riedel, W.R., 1979. Cretaceous to Neogene ichthyoliths in a giant piston core from the central North Pacific. Micropaleontology, $25: 337-364$.

Hovan, S.A., in press. Late Cenozoic atmospheric circulation intensity and climatic history recorded by eolian deposition in the eastern equatorial Pacific Ocean, Leg 138. In Pisias, N.G., Mayer, L.A., Janecek, T.R., Palmer-Julson, A., and van Andel, T.H. (Eds.), Proc. ODP., Sci. Results, 138: College Station, TX (Ocean Drilling Program).

Janecek, T.R., 1985. Eolian sedimentation in the Northwest Pacific Ocean: a preliminary examination of the data from Deep Sea Drilling Project Sites 576 and 578. In Heath, G.R., Burckle, L.H., et al., Init, Repts. DSDP, 86: Washington (U.S. Govt. Printing Office), 589-603.

Janecek, T.R., and Rea, D.K., 1983. Eolian deposition in the northeast Pacific Ocean: Cenozoic history of atmospheric circulation. Geol. Soc. Am. Bull., 94:730-738.

Kyte, F.T., Leinen, M., Heath, G.R., and Zhou, L., 1993. Cenozoic sedimentation history of the central North Pacific: inferences from the elemental geochemistry of Core LL44-GPC3. Geochim. Cosmochim. Acta, 57:1719-1740.

Kyte, F.T., and Wasson, J.T., 1986. Accretion rate of extraterrestrial matter: iridium deposited 33 to 67 million years ago. Science, 232:1225-1229.

Leinen, M., 1989. The pelagic clay province of the North Pacific Ocean. In Winterer, E.L., Hussong, D.M., and Decker, R.W. (Eds.), The Geology of North America (Vol. N): The Eastern Pacific Ocean and Hawaii. Geol. Soc. Am., 323-335,

Leinen, M., and Heath, G.R., 1981. Sedimentary indicators of atmospheric circulation in the Northern Hemisphere during the Cenozoic. Palaeogeogr., Palaeoclimatol., Palaeoecol., 36:1-21.

Mehra, O.P., and Jackson, M.L., 1960. Iron oxide removal from soils and clays by a dithionite-citrate system buffered with sodium bicarbonate. Clays Clay Miner, Proc. Conf., 7:317-327.
Nakai, S., Halliday, A.N., and Rea, D.K., 1993. Provenance of dust in the Pacific Ocean. Earth Planet. Sci. Lett., 119:143-157.

Prince, R.A., 1978. Southward motion of the Hawaiian hotspot between 42 and 25 MYBP. Geol. Soc. Am. Abstr. Progr., 10:474.

Prince, R.A., Heath G.R., and Kominz, K., 1980. Paleomagnetic studies of the central north Pacific sediment cores: stratigraphy, sedimentation rates, and the origin of magnetic instability. Geol. Soc. Am. Bull. (Pt. 2), 91:17891835.

Prospero, J.M., 1981. Eolian transport to the world ocean. In Emiliani, C. (Ed.), The Sea (Vol. 7): The Oceanic Lithosphere: New York (Wiley), 801-874

Pye, K., 1989. Processes of fine particle formation, dust source regions, and climatic changes. In Leinen, M., and Sarnthein, M. (Eds.), Paleoclimatology and Paleometeorology: Modern and Past Patterns of Global Atmospheric Transport: Boston (Kluwer Acad. Publ.), 3-30.

Rea, D.K., 1994. The paleoclimatic record provided by eolian deposition in the deep sea - the geologic history of wind. Rev. Geophys., 32:159-195.

Rea, D.K., Basov, I.A., Janecek, T.R., Palmer-Julson, A., et al., 1993. Proc. ODP, Init. Repts., 145: College Station, TX (Ocean Drilling Program).

Rea, D.K., and Harrsch, E.C., 1981. Mass accumulation rates of the nonauthigenic inorganic crystalline (eolian) component of deep sea sediments from Hess Rise, Deep Sea Drilling Program Sites 464, 465, and 466. In Thiede, J., Vallier, T.L., et al., Init. Repts. DSDP, 62: Washington (U.S Govt. Printing Office), 661-668.

Rea, D.K., and Janecek, T.R., 1981. Mass-accumulation rates of the nonauthigenic inorganic crystalline (eolian) component of deep-sea sediments from the western mid-Pacific Mountains, Deep Sea Drilling Project Site 463. In Thiede, J., Vallier, T.L., et al., Init. Repts. DSDP, 62: Washington (U.S. Govt. Printing Office), 653-659.

Rea, D.K., Leinen, M., and Janecek, T.R., 1985. A geological approach to the long-term history of atmospheric circulation. Science, 227:721-725.

Staudigel, H., Dole, P., and Zindler, A., 1985. Sr and Nd isotope systematics in fish teeth. Earth Planet. Sci. Lett., 76:45-56.

van Andel, T.H., Heath, G.R., and Moore, T.C., Jr., 1975. Cenozoic history and paleoceanography of the central equatorial Pacific Ocean: a regional synthesis of Deep Sea Drilling Project data. Mem.-Geol. Soc. Am., 143.

\footnotetext{
- Abbreviations for names of organizations and publications in ODP reference lists follow the style given in Chemical Abstracts Service Source Index (published by American Chemical Society).
}

Date of initial receipt: 4 April 1994

Date of acceptance: 19 September 1994

Ms 145SR-123 